\title{
Biodiversity of macrofaunal assemblages from three Portuguese submarine canyons (NE Atlantic)
}

\author{
Marina R. Cunha ${ }^{\mathrm{a}, *}$, Gordon L.J. Paterson ${ }^{\mathrm{b}}$, Teresa Amaro ${ }^{\mathrm{a}, \mathrm{c}}$, Sabena Blackbird ${ }^{\mathrm{d}}$, Henko C. de Stigter ${ }^{\mathrm{e}}$, \\ Clarisse Ferreira ${ }^{\mathrm{a}}$, Adrian Glover ${ }^{\mathrm{b}}$, Ana Hilário ${ }^{\mathrm{a}}$, Konstadinos Kiriakoulakis ${ }^{\mathrm{f}}$, Lenka Neal ${ }^{\mathrm{b}}$, \\ Ascensão Ravara ${ }^{a}$, Clara F. Rodrigues ${ }^{a}$, Áurea Tiago ${ }^{a}$, David S.M. Billett ${ }^{c}$ \\ ${ }^{a}$ CESAM \& Departamento de Biologia, Universidade de Aveiro, Campus Universitário de Santiago, 3810-193 Aveiro Portugal \\ ${ }^{\mathrm{b}}$ Natural History Museum, Cromwell Road, London, UK \\ c DEEPSEAS Group, Ocean Biogeochemistry and Ecosystems, National Oceanography Centre, Southampton, University of Southampton, Waterfront Campus, European Way, \\ Southampton SO143ZH, UK \\ ${ }^{\mathrm{d}}$ Department of Earth \& Ocean Sciences, University of Liverpool, 4 Brownlow Street, Liverpool L69 3BX, UK \\ e Royal Netherlands Institute for Sea Research (NIOZ), Texel, The Netherlands \\ ${ }^{\mathrm{f}}$ School of Natural Sciences and Psychology, Liverpool John Moores University, James Parsons Building, Byrom Street, Liverpool, Merseyside, UK, L3 3AF
}

\section{A R T I C L E I N F O}

Available online 16 April 2011

Keywords:

Submarine canyons

Biodiversity

Macrofauna

Deep-sea

Environmental conditions

\begin{abstract}
A B S T R A C T
The macrofaunal assemblages from three Portuguese submarine canyons, Nazaré, Cascais and Setúbal were studied from samples collected at their upper (900-1000 m), middle (3200-3500 m) and lower sections (4200-4500 m) and at the adjacent open slopes ( $\sim 1000 \mathrm{~m})$, during the HERMES cruises D297 (R.R.S. Discovery, 2005) CD179 (R.R.S. Charles Darwin, 2006) and 64PE252 (R.V. Pelagia, 2006). The taxonomic composition and patterns in biodiversity, abundance and community structure of the benthic macrofauna were described. Annelida (42.1\% of total abundance; 137 species) and Arthropoda (20.6\%; 162 species) were, respectively, the most abundant and the most species-rich Phyla among the 342 taxa identified during this study. Multivariate analyses showed significant differences between and within canyons and between canyons and open slope assemblages. At their upper section, canyons supported higher macrofauna abundance but slightly lower biodiversity than the adjacent slopes at similar depth. In all canyons abundance reached the highest value in the middle section and the lowest in the upper section, with marked fluctuations in Nazare (474-4599 ind. $\mathrm{m}^{-2}$ ) and lower variability in Cascais (583-1125 ind. $\mathrm{m}^{-2}$ ). The high abundance and dominance of the assemblages in the middle section of Nazaré and Setúbal was accompanied by depressed biodiversity, while in Cascais, Hurlbert's expected species richness showed increasing values from the upper to the middle canyon, and maintained the high values at the lower section. Overall, the Nazare Canyon showed the lowest expected species richness $\left(\mathrm{ES}_{(100)}: 16-39\right)$ and the Cascais Canyon the highest (39-54). There was a significant negative Kendall's correlation between total organic carbon concentrations in the superficial sediments and $\mathrm{ES}_{(100)}$ and a significant positive correlation between total nitrogen and macrofauna density. The influences of organic enrichment, sediment heterogeneity and hydrodynamic regime on the abundance, diversity and community structure of the macrofauna are discussed. It is suggested that altered and localised environmental conditions in the Portuguese canyons play an important role in modifying more common abundance and diversity bathymetric patterns evident in many continental slope environments.
\end{abstract}

(c) 2011 Elsevier Ltd. All rights reserved.

\section{Introduction}

Submarine canyons are complex and heterogeneous systems in terms of topography, hydrography, sedimentology and biogeochemistry. The biological complexity of their communities remains practically unknown (Weaver et al., 2004). Canyons are often referred to as depocenters and/or conduits for transport of particulate matter to the deep-sea (Gardner, 1989; Van Weering

\footnotetext{
* Corresponding author.

E-mail address: marina.cunha@ua.pt (M.R. Cunha).
}

et al., 2002; Palanques et al., 2005, Schlacher et al., 2007; De Leo et al., 2010; McClain and Barry, 2010; Vetter et al., 2010). They are generally recognised as organic enriched environments in comparison with the open slope at similar depths (Pusceddu et al., 2010). They also exhibit high levels of disturbance, for example, from the effects of bottom nepheloid layers, internal tides and other near bottom hydrodynamic processes, high variability in the direction and rate of transport and episodic strong down canyon flows (Vitorino et al., 2002; de Stigter et al., 2007).

Some canyons are closely connected to major river outflow systems while others funnel large quantities of sediment from the continental shelf into deep water, playing an important role in the 
transport of sediments and organic matter from the shore to deep basins (Sampere et al., 2008; De Leo et al., 2010). Particles transported along the submarine canyons may act locally as the major source of organic carbon to the benthos prevailing over the more common detritus rain from shallower waters (Vetter and Dayton, 1998). In the deep-sea, benthic macrofaunal assemblages are highly dependent on allochthonous organic matter (Rowe, 1981; Billett et al., 1983; Gooday, 2002; Rex et al., 2006; Smith et al., 2008) and their abundance usually declines with increasing water depth and increasing distance from shore (Sanders et al., 1965; Rowe, 1981; Rowe et al., 1982; Houston and Haedrich, 1984). The canyon fauna potentially experiences enhanced food supply through several mechanisms: (i) suspension feeders may benefit from accelerated currents (Rowe, 1971; Shepard et al., 1974); (ii) demersal planktivores may exploit dense layers of krill and zooplankton that become concentrated in canyons during downward vertical migrations; (iii) food for detritivores may be increased by high sedimentation rates in canyons not actively transporting sediment (Rowe et al., 1982) or through accumulation of macrophyte-detritus (Vetter, 1994, 1995). Not surprisingly, canyons are often reported as sustaining benthic assemblages with significant higher density or biomass than open slopes at comparable depths (Gage et al., 1995; Vetter, 1995; Vetter and Dayton, 1998; Duineveld et al., 2001).

There are some reports that submarine canyons may yield characteristic and unique faunas, but more often canyon macrofaunal assemblages show high dominance and biodiversity may be reduced locally (Rowe, 1971; Gage et al., 1995; Rogers et al., 2002; Curdia et al., 2004). In their lower sections, where canyons meet the abyssal plain, the faunal assemblages tend to be more similar to the ones in the surrounding environments. In most cases, the low taxonomic resolution and differences in the level of taxa identification hinders the comparability among studies as well as a full assessment of biodiversity and endemism (Gage et al., 1995; Escobar Briones et al., 2008).

The great spatial heterogeneity and temporal variability both among different canyons and within each individual system determine the ecology and the diversity of their benthic fauna (e.g. Schlacher et al., 2007). Canyon systems are highly variable in terms of topography, abundance and nature of suspended particles and patchiness in accumulation of sediment and organic matter; all with important effects on sediment grain size (e.g. de Stigter et al., 2007; Oliveira et al., 2007; Arzola et al., 2008). Different substrata allow the settlement of a wide variety of organisms and contrasting assemblages may be expected to occur under different hydrodynamic regimes (Thistle et al., 1985; Thistle and Wilson, 1996). Rapid, episodic flushing of canyons may mobilise large amounts of sediment, carrying it to the abyss and devastating benthic ecosystems over a wide area (Canals et al., 2006). The frequency of these potentially overwhelming events and the fluxes of particles produced are largely unknown but are expected to play a particularly important role in structuring benthic communities, both spatially and temporally. There is evidence that after the initial devastating effect, a relatively rapid recovery of the standing stocks may occur and the organic influxes may even act to enhance the recruitment of some benthic populations (Company et al., 2008).

The intermediate disturbance hypothesis (Connell, 1978), patch dynamics and other meta-community models (Leibold et al., 2004) have been used to address the importance of scale, heterogeneity, and frequency and intensity of disturbance in the explanation of the maintenance of deep-sea biodiversity (Gage et al., 1995; Levin et al., 2001; Cordes et al., 2010). Whether the predictions of such models can be used to determine the link between the environmental disturbance, noted within active canyons, and patterns of diversity and abundance has still to be tested and is investigated in Paterson et al. (2011).
The aim of this paper is to describe patterns in biodiversity, abundance and community structure of the benthic macrofauna in three Portuguese canyons: Nazaré, Cascais and Setúbal. Differences between and within canyons and differences between canyons and open slope assemblages are analysed using three sets of macrofauna data obtained during the R.R.S. Discovery cruise D297 in August 2005 (Weaver and shipboard scientific party, 2005, R.R.S. Charles Darwin cruise CD179 in April-May 2006 (Billet and shipboard scientific party, 2006) and R.V. Pelagia cruise 64PE252 in September 2006 (de Stigter and shipboard scientific party, 2006). The patterns of macrofauna abundance and diversity will be related to the environmental differences encountered within and among canyons, particularly the differences in biochemistry and physical disturbance down the canyons.

\section{Material and methods}

\subsection{Study area}

The Western Iberian Margin consists of a gently sloping, narrow shelf followed by the relatively steep continental slope which is incised by several submarine canyons oriented roughly perpendicular to the coast in an east-west direction. The area, under the influence of the Iberian system of the North Atlantic upwelling region, is subjected to seasonal hydrodynamic processes. Northerly winds, generating upwelling along the continental shelf, may occur from April to October, while during the winter dominant south-westerly winds establish a downwelling regime (Vitorino et al., 2002; Quaresma et al., 2007; Relvas et al., 2007). The occurrence of the Mediterranean Outflow, a high salinity water mass, flowing northwards along the margin between 600 and $1500 \mathrm{~m}$ also plays an important role in controlling circulation dynamics (Oliveira et al., 2007; Tyler et al., 2009). The Nazaré Canyon lies between $39^{\circ} 20^{\prime} \mathrm{N}$ and $39^{\circ} 40^{\prime} \mathrm{N}$. It is relatively simple but one of Europe's largest canyon systems. The Cascais and Setúbal canyons, located south of the Nazaré Canyon between $38^{\circ} 00^{\prime} \mathrm{N}$ and $38^{\circ} 30^{\prime} \mathrm{N}$, form a more complex system. The Setúbal Canyon is connected to two major river basins, the Tagus and the Sado. The proximal (upper and middle) sections of the canyons are characterised by a deeply incised, narrow, V-shaped thalweg, flanked by small gullies and terraces. The distal (lower) sections have a U-shaped floor with abundant erosional scours and depositional bedforms (Arzola et al., 2008).

In terms of sediment transport, the Nazaré Canyon is highly active, in particular during winter. In summer upwelling events may prevent sediment export (Pusceddu et al., 2010). Although the canyon does not connect to a river, the proximity of the head to the shore contributes to its effectiveness in capturing sediment transported along the shelf (de Stigter et al., 2007; Oliveira et al., 2007). High sedimentation rates are related to enhanced nepheloid layer activity especially at the upper section of the canyon (de Stigter et al., 2007; Arzola et al., 2008; Tyler et al., 2009). The concentration of suspended particulate matter is high at the benthic boundary layer and shows a marked decreasing trend from the upper to the lower section of the canyon (Tyler et al., 2009). Transport and rapid sediment accumulation are generally restricted to the upper and middle sections of the Nazaré Canyon (Lastras et al., 2009), but this is not a constant and unidirectional process. Internal tide-driven cycles of sediment resuspension, transport and deposition, alternate with quiescent intervals (de Stigter et al., 2007). Besides internal tides that operate more vigorously at the proximal sections of the canyon at time scales of hours (upper section) to weeks (middle section), sediment gravity flows may occur on a yearly or longer timescales and turbidity currents strong enough to transport sand down the canyon take 
place on a centennial timescale (de Stigter et al., 2007). The material captured in the canyon consists predominantly of terrigenous silt and clay (Alt-Epping et al., 2007; de Stigter et al., 2007; Arzola et al., 2008) and several studies point to chlorophyll- $a$ and organic carbon concentrations that are significantly higher in the canyon than in the adjacent open slope sediments (García et al., 2008; Ingels et al., 2009; Pusceddu et al., 2010).

Information on Cascais and Setúbal canyons is more limited. Small-scale $\left(<10 \mathrm{~km}^{2}\right)$ and localised mass wasting events characterise the upper section of Setúbal (Arzola et al., 2008 ) and

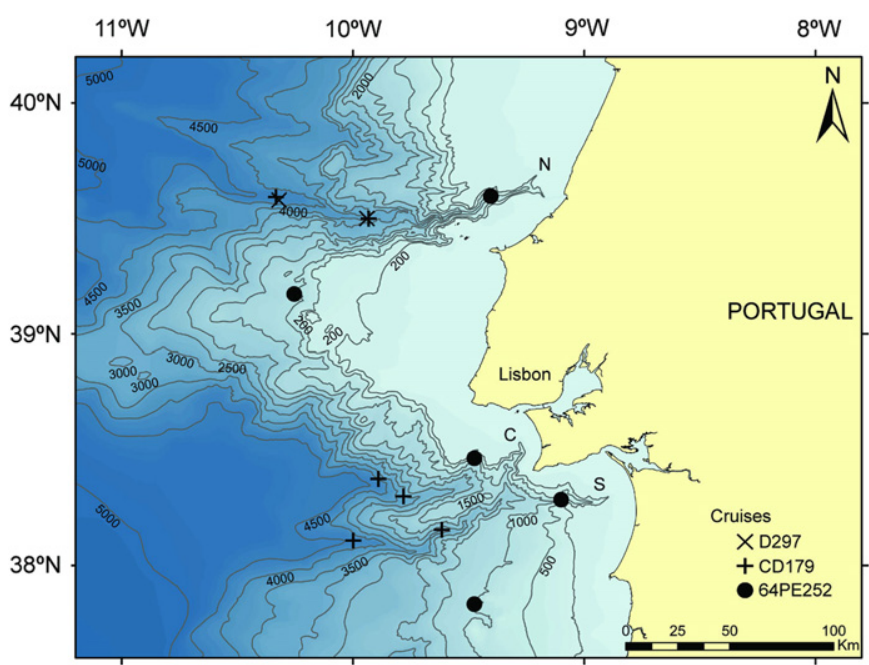

Fig. 1. Map of the study area in the Portuguese Margin with the sampling sites indicated. N: Nazaré Canyon; C: Cascais Canyon; S: Setúbal Canyon.
Cascais (Lastras et al., 2009) although slope failures in the lower sections are rare. Observed sedimentation rates in Setúbal are much lower than in Nazaré (Arzola et al., 2008). In Cascais, Pusceddu et al. (2010) reported higher chlorophyll- $a$ and organic carbon concentrations than in the adjacent open slope sediments but only in the upper section.

\subsection{Sample collection}

During R.R.S. Discovery cruise D297 macrofauna was sampled in the middle and lower canyon depositional (sedimentary) environments of the Nazare Canyon (Fig. 1, Table 1). In the middle canyon sampling occurred on a gently sloping sedimented platform on the lee-side of the thalweg at $3200-3500 \mathrm{~m}$. In the lower canyon sampling was undertaken in a large area of " $U$ " shaped valley floor at $4200-4500 \mathrm{~m}$ also to one side of the thalweg. Macrofauna samples (three deployments in each site) were taken using a USNEL box corer $\left(\right.$ area $=0.25 \mathrm{~m}^{2}$ ). During R.R.S. Charles Darwin cruise CD179 sampling was replicated at these two sites. In addition, further samples were taken at the same depths in the Cascais and Setúbal canyons (Fig. 1, Table 1). On this cruise four to five deployments were made at each site (providing a total of 27 replicates) using a UKORS Megacorer with multiple cylindrical cores $\left(0.008 \mathrm{~m}^{2}\right.$ internal area). From each deployment five to eight cores were taken for the macrofauna analysis (the pooled cores of each deployment were considered as one replicate of the respective station). In the upper canyons the topography is generally very steep, but some areas with slopes of moderate incline were evident and were suitable for focussed studies. During the R.V. Pelagia cruise 64PE252 samples were taken between 897 and $1030 \mathrm{~m}$ in all three canyons and on the adjacent open slopes south of Nazaré Canyon and Setúbal Canyon

Table 1

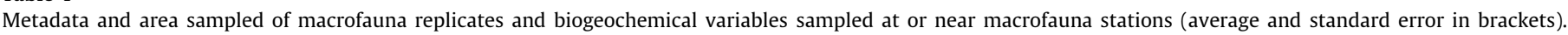
Depth, latitude and longitude refer to the range of the replicates taken in each station.

\begin{tabular}{|c|c|c|c|c|c|c|c|c|c|c|c|}
\hline Cruise & Code & Gear (n) & Date & $\begin{array}{l}\text { Depth } \\
(\mathrm{m})\end{array}$ & $\begin{array}{l}\text { Latitude } \\
(\mathrm{N})\end{array}$ & $\begin{array}{l}\text { Longitude } \\
\text { (W) }\end{array}$ & $\begin{array}{l}\text { Sampled } \\
\text { area }\left(\mathbf{m}^{2}\right)\end{array}$ & BS (n) & $\begin{array}{l}\text { TOC } \\
\left(\mathbf{m g ~ g}^{-1}\right)\end{array}$ & $\begin{array}{l}\mathrm{TN} \\
\left(\mathrm{mg} \mathrm{g}^{-1}\right)\end{array}$ & C:N \\
\hline D297 & NM05 & USNEL (3) & Aug. 2005 & $\begin{array}{l}3461 \\
3465\end{array}$ & $\begin{array}{l}39^{\circ} 30.02^{\prime} \\
39^{\circ} 30.62^{\prime}\end{array}$ & $\begin{array}{l}09^{\circ} 56.17^{\prime} \\
09^{\circ} 56.22^{\prime}\end{array}$ & 0.750 & 2 & $16.4(5.20)$ & $2.29(0.20)$ & $8.7(3.40)$ \\
\hline D297 & NL05 & USNEL (3) & Aug. 2005 & $\begin{array}{l}4336 \\
4367\end{array}$ & $\begin{array}{l}39^{\circ} 34.99^{\prime} \\
39^{\circ} 35.02^{\prime}\end{array}$ & $\begin{array}{l}10^{\circ} 18.95^{\prime} \\
10^{\circ} 19.04^{\prime}\end{array}$ & 0.750 & 4 & $17.3(0.74)$ & $1.59(0.07)$ & $12.7(0.17)$ \\
\hline CD179 & NM & UKORS (4) & May 2006 & $\begin{array}{l}3517 \\
3522\end{array}$ & $\begin{array}{l}39^{\circ} 29.95^{\prime} \\
39^{\circ} 30.00^{\prime}\end{array}$ & $\begin{array}{l}09^{\circ} 55.97^{\prime} \\
09^{\circ} 56.01^{\prime}\end{array}$ & 0.220 & 2 & $20.2(0.65)$ & $2.23(0.12)$ & $10.6(0.21)$ \\
\hline CD179 & $\mathrm{NL}$ & UKORS (4) & May 2006 & $\begin{array}{l}4403 \\
4418\end{array}$ & $\begin{array}{l}39^{\circ} 35.55^{\prime} \\
39^{\circ} 35.58^{\prime}\end{array}$ & $\begin{array}{l}10^{\circ} 19.99^{\prime} \\
10^{\circ} 20.06^{\prime}\end{array}$ & 0.181 & 2 & $19.0(1.45)$ & $1.85(0.16)$ & $\begin{array}{l}12.1 \\
(1.95)\end{array}$ \\
\hline CD179 & $\mathrm{CM}$ & UKORS (5) & Apr. 2006 & $\begin{array}{l}3199 \\
3219\end{array}$ & $\begin{array}{l}38^{\circ} 17.96^{\prime} \\
38^{\circ} 18.02^{\prime}\end{array}$ & $\begin{array}{l}09^{\circ} 46.87^{\prime} \\
09^{\circ} 47.07^{\prime}\end{array}$ & 0.298 & 2 & $13.5(0.35)$ & $1.91(0.05)$ & $8.2(0.01)$ \\
\hline CD179 & $\mathrm{CL}$ & UKORS (4) & May 2006 & $\begin{array}{l}4241 \\
4245\end{array}$ & $\begin{array}{l}38^{\circ} 22.49^{\prime} \\
38^{\circ} 22.50^{\prime}\end{array}$ & $\begin{array}{l}09^{\circ} 53.40^{\prime} \\
09^{\circ} 53.52^{\prime}\end{array}$ & 0.251 & 1 & $11.2(-)$ & $1.42(-)$ & $9.2(-)$ \\
\hline CD179 & SM & UKORS (5) & Apr. 2006 & $\begin{array}{l}3224 \\
3275\end{array}$ & $\begin{array}{l}38^{\circ} 09.22^{\prime} \\
38^{\circ} 09.29^{\prime}\end{array}$ & $\begin{array}{l}09^{\circ} 36.94^{\prime} \\
09^{\circ} 36.93^{\prime}\end{array}$ & 0.314 & 1 & $13.0(-)$ & $2.12(-)$ & $7.2(-)$ \\
\hline CD179 & SL & UKORS (5) & May 2006 & $\begin{array}{l}4482 \\
4485\end{array}$ & $\begin{array}{l}38^{\circ} 06.45^{\prime} \\
38^{\circ} 06.52^{\prime}\end{array}$ & $\begin{array}{l}09^{\circ} 59.94^{\prime} \\
09^{\circ} 59.99^{\prime}\end{array}$ & 0.306 & 1 & $10.6(-)$ & $1.62(-)$ & $7.7(-)$ \\
\hline 64PE252 & NU & NIOZ (2) & Sep. 2006 & 897 & $39^{\circ} 35.80^{\prime}$ & $\begin{array}{l}09^{\circ} 24.24^{\prime} \\
09^{\circ} 24.25^{\prime}\end{array}$ & 0.393 & - & - & - & - \\
\hline 64PE252 & $\mathrm{CU}$ & NIOZ (3) & Sep. 2006 & $\begin{array}{r}935 \\
1020\end{array}$ & $\begin{array}{l}38^{\circ} 27.86^{\prime} \\
38^{\circ} 27.90^{\prime}\end{array}$ & $\begin{array}{l}09^{\circ} 28.49^{\prime} \\
09^{\circ} 28.51^{\prime}\end{array}$ & 0.589 & - & - & - & - \\
\hline 64PE252 & SU & NIOZ (3) & Sep. 2006 & 970 & $38^{\circ} 17.10^{\prime}$ & $\begin{array}{l}09^{\circ} 05.98^{\prime} \\
09^{\circ} 06.01^{\prime}\end{array}$ & 0.589 & - & - & - & - \\
\hline 64PE252 & OSN & NIOZ (2) & Sep. 2006 & 1030 & $39^{\circ} 10.36^{\prime}$ & $\begin{array}{l}10^{\circ} 15.23^{\prime} \\
10^{\circ} 15.23^{\prime}\end{array}$ & 0.393 & - & - & - & - \\
\hline 64PE252 & OSS & NIOZ (3) & Sep. 2006 & 1001 & $\begin{array}{l}37^{\circ} 49.95^{\prime} \\
37^{\circ} 49.99^{\prime}\end{array}$ & $\begin{array}{l}09^{\circ} 28.49^{\prime} \\
09^{\circ} 28.50^{\prime}\end{array}$ & 0.589 & - & - & - & - \\
\hline
\end{tabular}

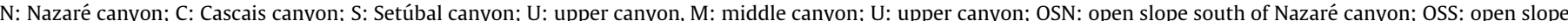
south of Setúbal canyon; n: number of replicates; BS: biogeochemical samples; TOC: total organic carbon; TN: total nitrogen; C:N: molar carbon to nitrogen ratio. 
(Fig. 1, Table 1). These five stations were sampled (2-3 deployments per site) with the NIOZ circular box corer $\left(\right.$ area $\left.=0.196 \mathrm{~m}^{2}\right)$.

\subsection{Environmental variables}

Sediment cores for total organic carbon (TOC) and total nitrogen (TN) analyses were collected at or near macrofauna stations (see Table 1) using a UKORS multi-corer. The cores were frozen upon recovery, extruded when still frozen, wrapped in precombusted $\left(400{ }^{\circ} \mathrm{C} ; 4 \mathrm{~h}\right)$ foil and stored in $-80^{\circ} \mathrm{C}$ for the duration of the cruise. These were sliced on return to the laboratory, every $\mathrm{cm}$ down to $6 \mathrm{~cm}$ and every $2 \mathrm{~cm}$ down to $10 \mathrm{~cm}$. Aliquots of freeze-dried sediments (5-10 mg) were decarbonated using acid vapour (Yamamouro and Kayanne, 1995) in order to determine TOC content $\left(\mathrm{mg} \mathrm{g}^{-1}\right)$ of the dry sediment. Non-decarbonated aliquots were used to determine TN. All carbon and nitrogen elemental analyses were carried out using a CEInstruments NC $2500 \mathrm{CHN}$ analyser in duplicate (mean value used; all values were within $10 \%$ of the mean).

\subsection{Macrofauna sample processing}

In all cruises the sample processing was initiated onboard by sub-sampling the different depth layers of the sediment. The material was sliced at $0-1,1-3,3-5,5-10,10-15$ and whenever possible also $15-20 \mathrm{~cm}$ following the standard techniques adopted as general practice in HERMES. The supernatant water on box cores and megacores was passed through the $300 \mu \mathrm{m}$ sieve to retain any small fauna resuspended during sampling and core retrieval on deck. The sediment layers $0-1$ and $1-3 \mathrm{~cm}$ where placed immediately in formalin, prior to sieving and the deeper layers were carefully washed with seawater through $1 \mathrm{~mm}$, $500 \mu \mathrm{m}$ and $300 \mu \mathrm{m}$ sieves. The sieved material was fixed immediately in $10 \%$ buffered formalin diluted in seawater, or in $96 \%$ ethanol (in the case of cruise 64PE252). The material from the $1 \mathrm{~mm}$ and $500 \mu \mathrm{m}$ sieves was sorted under a stereo microscope and kept in $96 \%$ ethanol for further taxonomic identification. The material from the $300 \mu \mathrm{m}$ sieves was not analysed and it was stored for future studies.

The specimens were all sorted into major taxa and then identified to species level whenever possible. Although many taxa were not yet ascribed a species name, they were all sorted into putative species and ascribed a codename consistent throughout the samples. Therefore the estimated species richness can be considered as accurate.

Species abundance was determined for each sediment layer in each replicate but for the purposes of this paper sediment layers' values were not used and densities were calculated as the pooled number of individuals in relation to the area sampled and expressed as individuals per $\mathrm{m}^{2}$ (ind. $\mathrm{m}^{-2}$ ).

\subsection{Data analysis}

Each deployment in a given station (depth) was treated as a replicate and therefore small-scale variability was not dealt with (e.g. all cores in a megacore deployment were pooled in just one replicate)

Species richness, Shannon-Wiener diversity index $\left(H^{\prime}\right)$, Pielou (1969) evenness index $\left(J^{\prime}\right)$ and Hurlbert (1971) expected species richness $\left(\mathrm{ES}_{(n)}\right)$, were calculated using the community analysis PRIMER v6 software (Clarke and Gorley, 2006). Distributional analysis of the macrofaunal community structure was carried out using k-dominance curves (Lambshead et al., 1983). The significance of non-parametric Kendall correlation $(\tau)$ (Kendall, 1938) between the geochemical variables and macrofauna abundance and $\mathrm{ES}_{(100)}$ was assessed.
PRIMER v6 software (Clarke and Gorley, 2006) was also used for multivariate analyses. Because different sampling areas and gear were used during the three cruises three sets of data were organized and analyzed separately. The first dataset included the samples taken in the middle and lower Nazare Canyon during cruises D297 and CD197. The analysis assessed differences in relation to depth and sampling period. The interpretation of results takes into account the differences in sampled area and gear used. The second dataset included only the samples collected during cruise CD197 in the middle and lower sections of the three canyons. The analysis was focused on the assessment of differences among canyons and between depths. Finally, the third dataset included all samples collected during cruise 64PE252 in the upper section of the three canyons and two sites on the adjacent open continental slopes. Because of the insufficient number of replicates on each site during this cruise, differences between canyons could not be assessed and the analysis was focused only on the differences between canyons and open slopes.

For each analysis, the abundance data (ind. $\mathrm{m}^{-2}$ ) were first organized into a sample vs. species matrix. Non-metric multidimensional scaling (MDS) ordination was performed using the Bray-Curtis similarity measure, after fourth root transformation of the data. An analysis of similarities by randomization/permutation tests (ANOSIM) was performed on the MDS results of samples grouped according to the relevant factors. Dataset 1 (Nazaré): two-way crossed layout with the factors 'Cruise' (D297, CD179) and 'Depth' (Middle, Lower); Dataset 2 (Three Canyons): two-way crossed layout with the factors 'Canyon' (Nazaré, Cascais, Setúbal) and 'Depth' (Middle, Lower); Dataset 3 (UC vs. OS): one-way layout with Upper Canyon (UC) vs. Open Slope (OS) samples. SIMPER analysis (Similarity Percentages - species contributions) was performed in all cases to indicate the percentage contributions of each species to the similarity within and dissimilarity between groups of samples.

\section{Results}

\subsection{Macrofaunal assemblages}

A total of 6283 specimens were ascribed to 342 taxa. Annelida (42.1\% of total abundance; 137 species) were the most abundant phylum and Arthropoda (20.6\%; 162 species) were the most speciesrich. Mollusca showed intermediate values of abundance and species richness (34.2\%; 38 species) and Echinodermata were much less common (3.1\%; 6 species). The only other phylum represented in the samples was the Sipuncula ( $<0.01 \% ; 2$ species).

The Annelida, exclusively Polychaeta, were represented by 82 species in Nazaré, 75 in Cascais and 77 in Setúbal; the species richness per site (Fig. 2, Table 2) varied from 17 in the open slope south of Nazare (OSN) to 38 in the middle section of Cascais (CM). Polychaetes were abundant at all sites and often dominated the macrofaunal assemblage (Figs. 3 and 4). Their greatest relative contribution in terms of abundance was recorded in the lower Nazare (NL: 80.4\% in 2006). The Spionidae, Siboglinidae and Ampharetidae (Canalipalpata) were the most abundant families in the middle and lower sections of all canyons and Onuphidae and Lumbrineridae (Aciculata) in the upper canyons areas. The polychaete assemblages are discussed in more detail by Paterson et al. (2011).

The Arthropoda, exclusively Crustacea, were represented by 80 species both in Cascais and in Setúbal and 54 species in Nazaré; the species richness per site (Fig. 2, Table 2) ranged from 13 in the upper section of Nazare (NU) and OSN to 52 in the middle section of Setúbal (SM). Crustacea dominated the assemblages in CM (45.9\% of the total abundance) and in the open slope south of Setúbal (OSS: 55.0\%), and almost matched the polychaete 


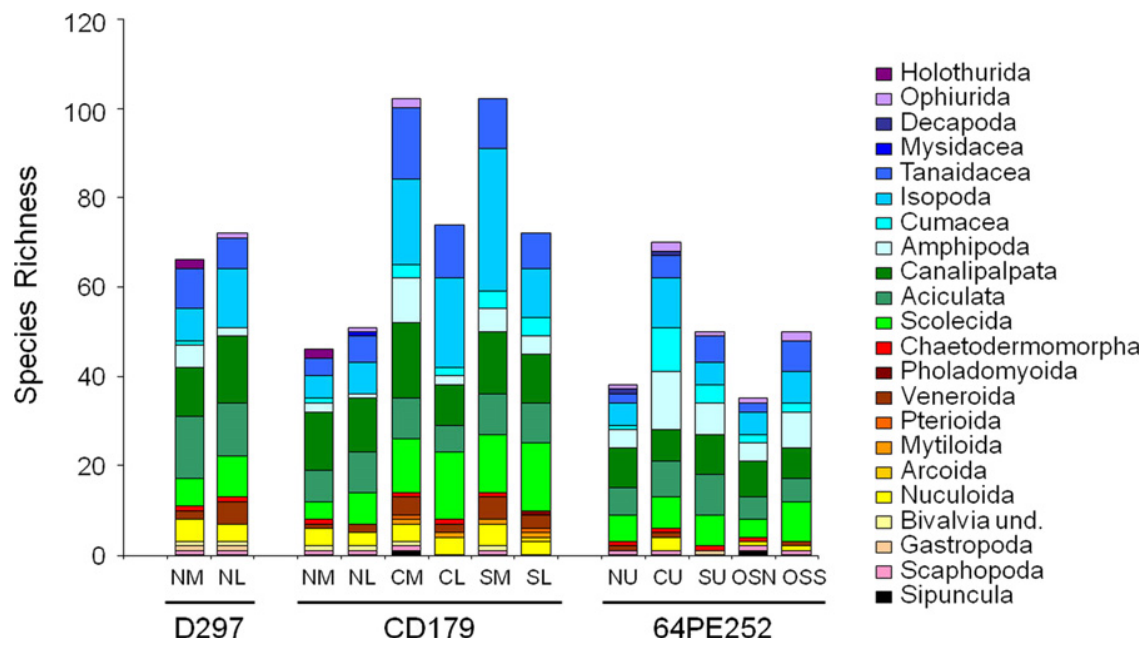

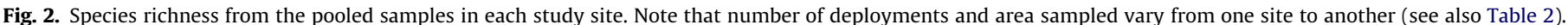

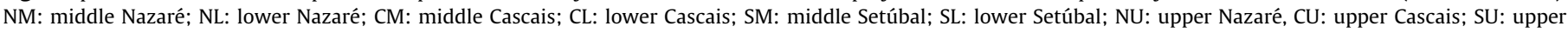
Setùbal; OSN: open slope south of Nazaré; OSS: open slope south of Setúbal.

Table 2

Abundance and biodiversity data for macrofauna samples.

\begin{tabular}{|c|c|c|c|c|c|c|c|c|c|}
\hline SITE & $n$ & $A\left(\mathrm{~m}^{2}\right)$ & $N$ & $D$ (ind. $\mathrm{m}^{-2}$ ) & SE & $S$ & $H^{\prime}$ & $J^{\prime}$ & $\mathrm{ES}_{(100)}$ \\
\hline NM05 & 3 & 0.750 & 2137 & 2849.3 & 589.2 & 66 & 2.05 & 0.490 & 16.9 \\
\hline NL05 & 3 & 0.750 & 601 & 801.3 & 77.3 & 72 & 3.25 & 0.760 & 33.4 \\
\hline NM & 4 & 0.220 & 1011 & 4599.5 & 441.6 & 46 & 1.87 & 0.489 & 16.1 \\
\hline NL & 4 & 0.220 & 249 & 1125.9 & 194.0 & 51 & 2.13 & 0.541 & 28.3 \\
\hline CM & 5 & 0.307 & 332 & 1125.1 & 138.0 & 102 & 4.12 & 0.891 & 53.8 \\
\hline CL & 4 & 0.252 & 181 & 718.3 & 20.9 & 74 & 4.01 & 0.932 & 53.9 \\
\hline SM & 5 & 0.315 & 706 & 2241.3 & 164.2 & 102 & 3.09 & 0.668 & 35.5 \\
\hline SL & 5 & 0.307 & 200 & 653.4 & 77.2 & 71 & 3.76 & 0.883 & 49.1 \\
\hline NU & 2 & 0.392 & 186 & 474.5 & 102.0 & 37 & 2.96 & 0.821 & 28.4 \\
\hline $\mathbf{C U}$ & 3 & 0.586 & 343 & 583.3 & 19.2 & 70 & 3.51 & 0.826 & 39.4 \\
\hline SU & 2 & 0.392 & 151 & 385.2 & 63.8 & 50 & 3.58 & 0.915 & 41.8 \\
\hline OSN & 2 & 0.392 & 75 & 191.3 & 48.5 & 35 & 3.21 & 0.903 & $35.0^{*}$ \\
\hline OSS & 3 & 0.586 & 111 & 188.8 & 29.5 & 50 & 3.60 & 0.920 & 47.1 \\
\hline UC & 7 & 1.370 & 680 & 495.6 & 43.5 & 100 & 3.88 & 0.842 & 44.7 \\
\hline OS & 5 & 0.978 & 186 & 189.8 & 22.3 & 69 & 3.89 & 0.920 & 50.3 \\
\hline $\mathbf{N}$ & 16 & 2.332 & 4184 & - & - & 158 & - & - & 27.0 \\
\hline C & 12 & 1.145 & 856 & - & - & 192 & - & - & 63.0 \\
\hline $\mathbf{S}$ & 12 & 1.014 & 1057 & - & - & 179 & - & - & 50.6 \\
\hline AC & 40 & 4.491 & 6097 & - & - & 326 & - & - & 41.9 \\
\hline
\end{tabular}

$n$ : number of deployments pooled; $A$ : area sampled; $N$ : number of individuals; $D$ : density; SE: standard error; $S$ : species richness; $H^{\prime}$ : Shanon-Wienner diversity; $J$ ' Pielou's evenness; $\mathrm{ES}_{(100)}$ : Hulbert's expected number of species per 100 individuals; NM05: middle Nazaré in 2005; NL05: lower Nazaré in 2005 NM: middle Nazaré, NL: lower Nazaré; CM: middle Cascais; CL: lower Cascais; SM: middle Setúbal; SL: lower Setúbal; NU: upper Nazaré, CU: upper Cascais; SU: upper Setùbal; OSN: open slope south of Nazaré; OSS: open slope south of Setúbal; UC: pooled upper canyon samples; OS: pooled open slope samples; N: Nazaré pooled samples; C: Cascais pooled samples; S: Setúbal pooled samples; AC: all canyon samples pooled.

abundances in the lower Cascais (CL: 41.4\%) and NU (40.9\%) (Figs. 3 and 4). Amphipoda and Cumacea reached their highest diversity and abundance at shallower sites and Isopoda at greater depths. Among the amphipods, the Ampeliscidae and Melitidae were restricted to the shallower sites, while the Phoxocephalidae were particularly abundant in the Cascais and Setúbal canyons. Cumaceans were also most diverse and abundant in these two canyons (although to a lesser extent in Setúbal). Among isopods, anthurid and cirolanid families were restricted to shallower sites, and Macrostylidae and Ischnomesidae to the middle and lower sections. In Cascais and Setúbal, also at the middle and lower sections, Desmosomatidae (the most species-rich crustacean family) and Nannoniscidae reached their highest relative contributions. Tanaidomorpha, particularly Pseudotanaidae in Nazaré, were very

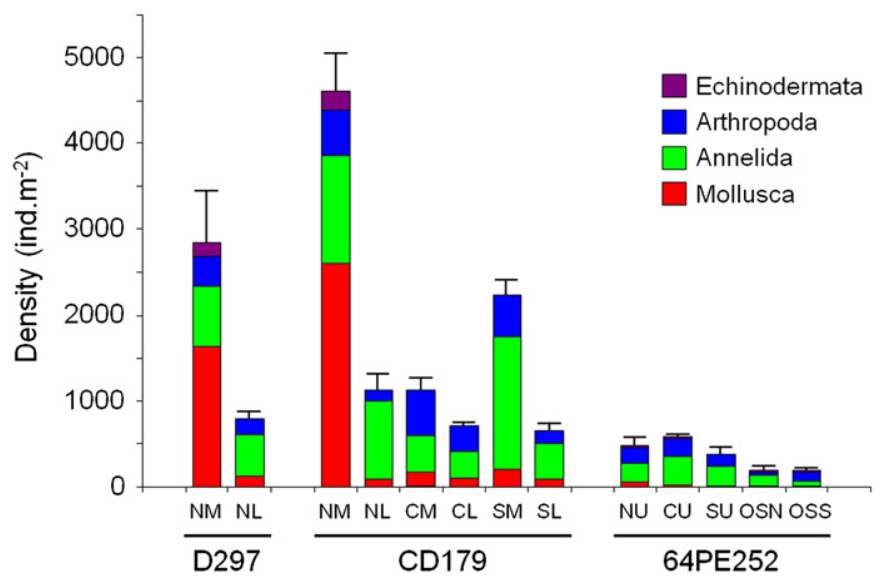

Fig. 3. Abundance of macrofauna (average number of individuals per $\mathrm{m}^{2}$ and standard error bars) in each study site. NM: middle Nazaré; NL: lower Nazaré; CM: middle Cascais; CL: lower Cascais; SM: middle Setúbal; SL: lower Setúbal; NU: upper Nazaré, CU: upper Cascais; SU: upper Setùbal; OSN: open slope south of Nazaré; OSS: open slope south of Setúbal.

abundant at the deeper sites while Apseudomorpha were restricted to the shallower sites.

The Mollusca were represented mostly by bivalves of the Orders Nuculoida (13 taxa) and Veneroida (10 taxa). There were 18 species recorded both in Nazaré and in Cascais and 21 species in Setúbal; the species richness per site (Fig. 2, Table 2) ranged from 2 in the upper canyon of Setúbal (SU) to 14 in SM. Molluscs were very rare in the upper canyons and open slope where only a few specimens were collected but Aplacophora (Chaetodermomorpha) were the dominant group in the middle section of Nazaré (NM) accounting for $47.0 \%$ and $49.6 \%$ of the total abundance in 2005 and 2006, respectively (Fig. 4). The most abundant bivalves were Yoldiidae and Nuculanidae (Nuculanoida) at CL, SL and NM, and Thyasiridae (Veneroida) at CM, SM and NL.

These differences in the taxonomic composition result in important differences in the size structure (and hence biomass) and trophic diversity of the assemblages. At the shallower sites there were important contributions, both in relative abundance and species richness, of larger-sized crustaceans (e.g. Melitidae, Cirolanidae, Apseudomorpha) and polychaetes (usually highly mobile carnivores or omnivores e.g. Onuphidae and Lumbrineridae). At the deeper sites the assemblages were dominated by highly 
N
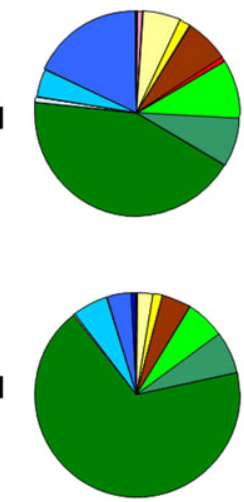

C

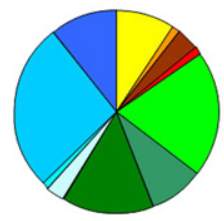

s

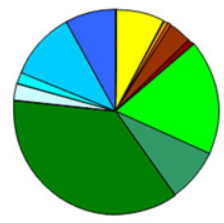

$\mathbf{L}$
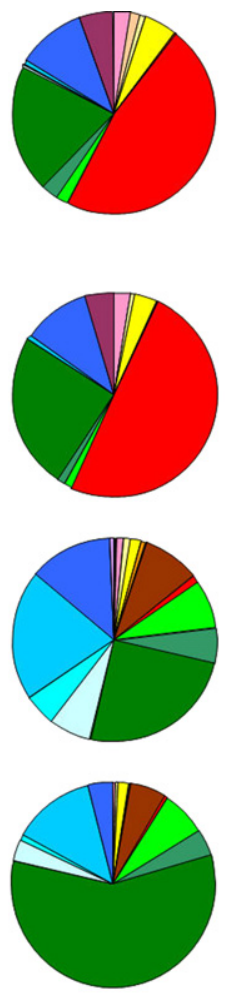

M

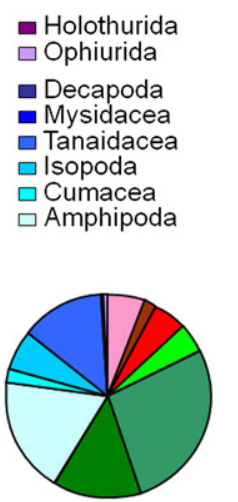

- Canalipalpata

$\square$ Aciculata

Scolecida

Chaetodermomorpha

- Pholadomyoida

- Veneroida

$\square$ Pterioida

$\square$ Mytiloida

$\square$ Arcoida

$\square$ Nuculoida

$\square$ Bivalvia und.

$\square$ Gastropoda

$\square$ Scaphopoda

- Sipuncula
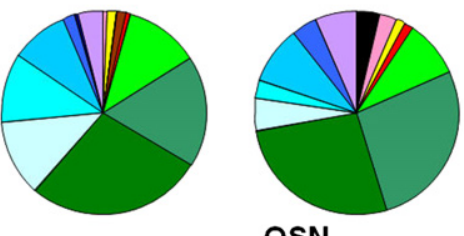

OSN

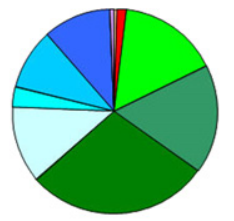

U

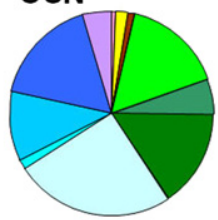

oss

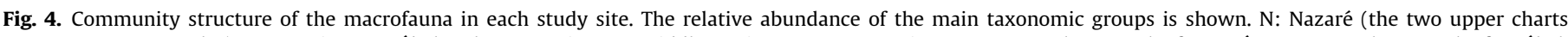

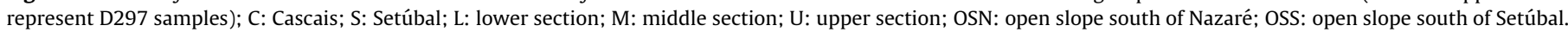

abundant, small sized, poorly mobile, opportunistic surface and subsurface deposit feeders (Spionidae, Chaetodermomorpha, Asellota isopods, Tanaidomorpha tanaids). In the middle section of Nazare Canyon just two taxa (Prionospio sp. A and Chaetodermomorpha) accounted for approximately $70 \%$ of the total abundance. The dominance of deposit feeders (including the Spionidae that may switch between deposit and suspension feeding) was greater than $90 \%$. In the lower section of Nazaré and middle and lower sections of the two other canyons, obligate or potential facultative chemotrophs (Siboglinidae and Thyasiridae) were present and accounted for up to $16 \%$ and $19 \%$ of the total abundance (at SL and CM, respectively).

Besides the important changes in their composition, the macrofaunal assemblages showed different trends in abundance and biodiversity (i) along the depth gradient and (ii) among canyons. In all canyons abundance reached the greatest values in the middle canyon sections and the lowest in the upper sections, with marked fluctuations in Nazare and lower variability in Cascais. All canyons showed similar abundances in the upper canyon sections while in the middle and lower sections the greatest abundances occurred in Nazaré. Abundance in Setúbal Canyon was noticeably higher than in Cascais only in the middle section but not in the lower (Fig. 2, Table 2). The fluctuations in abundance and specific composition are reflected in the differences in the community structure illustrated by $J$ values (Table 2) and k-dominance curves (Fig. 5). The assemblages from the upper sections of all canyons showed low dominance and high evenness. This was evident in the Cascais Canyon at all depths. In Setúbal the middle section showed increased dominance and there were highly dominated, uneven assemblages in the lower canyon. The macrofauna of middle section of Nazaré Canyon had the highest dominance.

Hurlbert's expected species numbers and rarefaction curves are shown in Table 2 and Fig. 6 . This index, originally designed to allow comparisons of non-quantitative samples, is sensitive to both evenness and species richness (Gage and May, 1993) and can be normalised to the same number of individuals ( $n$, typically equal or lower than the lowest common number of individuals). It is, therefore, an adequate biodiversity estimate for the present study because of the differences in abundance and sampling discrepancies in the different sites. The rarefaction curves (Fig. 6) all show relatively steep slopes and are far from reaching asymptotic values revealing that the sampling effort is insufficient to assess the full biodiversity either at individual sites or at larger scales. In fact, only a few thousands of individuals were obtained during this study and the number of individuals collected per site (pooled values from the different deployments, Table 2) ranged from only 75 in OSN to 2137 in NM (in 2005). Hurlbert's $\mathrm{ES}_{(100)}$ values ranged from 16.1 (NM in 2006) to 53.9 (CL). At all depths Nazaré Canyon shows the lowest $\mathrm{ES}_{(100)}$ and Cascais the highest (with the exception of the upper section in Setúbal). Changes in biodiversity with the depth gradient are similar in Nazaré and Setúbal with comparable $\mathrm{ES}_{(100)}$ values in the upper and lower canyon areas (slightly higher in the latter) and the lowest values at intermediate depths. In Cascais the lowest biodiversity is in the upper canyon. Comparable $\mathrm{ES}_{(100)}$ values occur in the middle and lower canyon sections. In Cascais and Setúbal the $\mathrm{ES}_{(100)}$ values (Table 2) estimated from pooled samples along the bathymetric gradient (C: 63.0; S: 50.6) are higher than any of the individual sites within the canyons. However, the high dominance and abundance of the assemblage in the middle Nazaré determined a much lower $\mathrm{ES}_{(100)}$ value for the pooled samples in this canyon (27.0) and also for the global value of the three canyons altogether (41.9).

\subsection{Environmental data}

The sediment concentrations of TOC and TN, and molar C:N ratio values in middle and lower sections of the three canyons are shown in Table 1 . TOC values ranged from 10.6 (SL) to $20.2 \mathrm{mg} \mathrm{g}^{-1}$ (NM, in 2006). TOC concentrations were higher in 

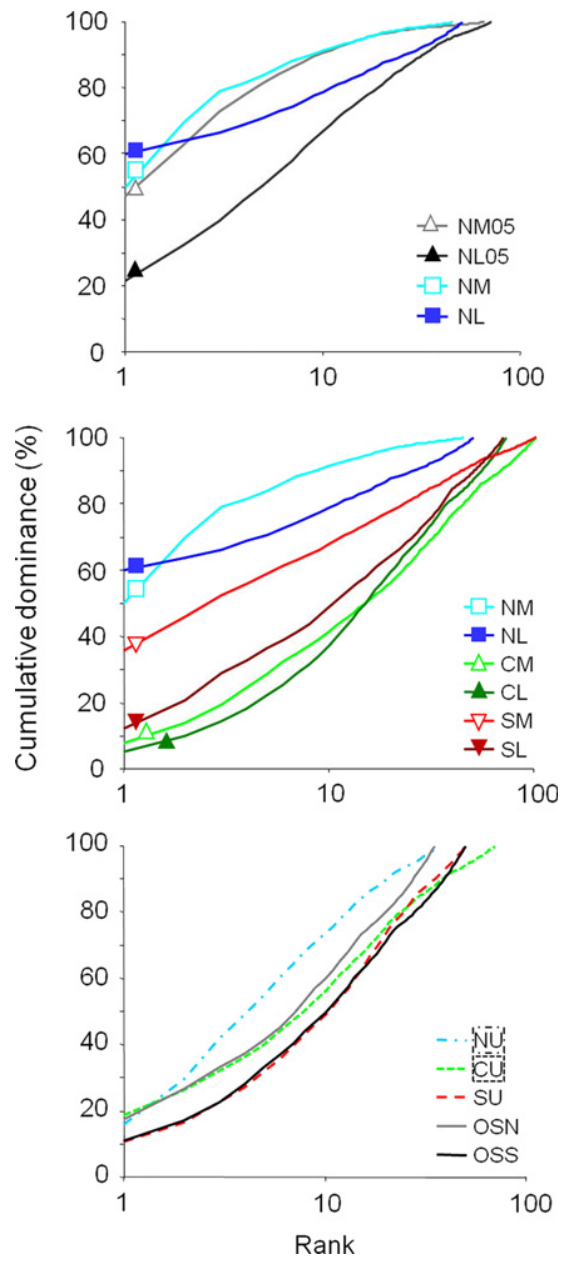

Fig. 5. Comparison of k-dominance curves of different study sites. A: Nazaré stations at the upper and middle canyons samples during two consecutive cruises using different sampling gear. B: Middle and lower sections of the three canyons sampled during cruise CD179. C: Upper canyon and open slope sites sampled during cruise 64PE252. NM05: middle Nazaré in 2005; NL05: lower Nazaré in 2005 NM: middle Nazaré, NL: lower Nazaré; CM: middle Cascais; CL: lower Cascais; SM: middle Setúbal; SL: lower Setúbal; NU: upper Nazaré, CU: upper Cascais; SU: upper Setùbal; OSN: open slope south of Nazaré; OSS: open slope south of Setúbal.

Nazare than in the other two canyons and were greatest at intermediate depths of all canyons. TN values varied from 1.62 (SL) to $2.29 \mathrm{mg} \mathrm{g}^{-1}$ (NM, in 2005) with the same pattern observed for TOC, but in this case differences between canyons were smaller and the decrease from the middle to the lower sections was more accentuated, resulting in an increase of molar C: $\mathrm{N}$ ratio values with increasing depth. Molar C:N were lower than 8.0 in Setúbal and the highest in the Nazaré Canyon (12.7, NL in 2005). Kendall's correlation between the environmental variables and density and biodiversity $\left(\mathrm{ES}_{(100)}\right)$ of the macrofauna were estimated: a negative correlation between TOC concentrations and $\mathrm{ES}_{(100)}$ $(\tau=-0.843 ; p<0.05)$ and a positive correlation between TN and density $(\tau=0.714 ; p<0.05)$ showed significant values. All other cases were not significant. The values of these environmental variables and community descriptors are plotted together in Fig. 7 showing the opposite trends in the variation of TOC and $\mathrm{ES}_{(100)}$ and the parallel trends in the variation of TN and macrofauna density.

\subsection{Multivariate analysis}

\subsubsection{Cruise D297 vs. cruise CD197 in the Nazaré Canyon}

Two sites (NM and NL) were sampled with different devices in consecutive years (USNEL boxcore in 2005-cruise D297 and
UKORS megacore in 2006-cruise CD197). Therefore the results of this analysis are likely to be influenced both by differences in the sampling gear and temporal changes in the assemblages. The MDS plot (Fig. 8A) shows a clear segregation of the samples obtained during D297 (August 2005) and CD179 (April-May 2006). The higher dispersion in the CD179 deployments is also obvious and may be explained by the smaller area sampled and subsequently lower number of species collected per replicate. Total density estimates for 2006 show important increases relative to 2005 (Table 2 ) but these are not statistically significant (NM: $t=2.346, \mathrm{df}=5, p>0.05 ; \mathrm{NL}: t=1.361, \mathrm{df}=5, p>0.2$ ). However, ANOSIM results indicate that both 'Cruise' and 'Depth' differences are significant (Table 3 ) with prevalence of the latter (higher $R$ and significance of the ANOSIM test). The similarity within groups and the dissimilarity between groups (Table 4) also show higher values for the factor 'Depth' (averaged between 'Cruise' groups). SIMPER results further indicate that the differences are explained mainly by abundance variations in the most dominant species in all samples: the increase in Chaetodermomorpha and Prionospio sp. A and decrease in Pseudotanaidae sp051 from 2005 to 2006 are responsible for $60 \%$ of the dissimilarity between 'Cruise' groups. The same species, all more abundant at the middle canyon, contribute $67 \%$ to the dissimilarity between 'Depth' groups. Differences in the species composition of the assemblages (e.g. the absence of the two holothurian species in the lower canyon) contribute much less to the dissimilarity between groups. The comparison of the rarefaction curves (Fig. 6) shows a high similarity in the biodiversity estimates obtained in the two consecutive years at each site although k-dominance curves (Fig. 5) indicate a shift in the structure of the NL assemblage towards higher dominance in 2006.

\subsubsection{CD179-comparison between and within canyons}

The analyses performed on the results of the cruise CD179 illustrate a good segregation of the deployments from different sites (Fig. 8B) and indicate highly significant differences both among canyons and between depths (Table 3). SIMPER results (Table 5) show high values of average dissimilarity between groups for both factors ('Canyon' and 'Depth') but low values of average similarity within groups. The major contributors for the differences between canyons are Prionospio sp. A (all canyons), Chaetodermomorpha and Pseudotanaidae sp051 (N vs. C and S) and Melinampharete sp. A ( $\mathrm{S}$ vs. $\mathrm{N}$ and $\mathrm{C}$ ). These species are responsible for ca. 50\% of the dissimilarity between Nazare and the other two canyons but only $19.5 \%$ of the dissimilarity between Cascais and Setúbal. In fact the dissimilarity between these two canyons is accounted for by a large number of species with very low percentage contributions. The average within-canyon similarities in Cascais and Setúbal are also much lower than in Nazaré. When all three canyons are considered together, five species contribute $41 \%$ of the dissimilarity between the middle and lower sections (Chaetodermomorpha, Prionospio sp. A, Prionospio sp. B, Melinampharete sp. A, Pseudotanaidae sp. 051).

\subsubsection{Canyon vs. open slopes}

The MDS analysis performed on the results of the cruise 64PE252 shows a clear segregation of the samples from canyons and open slopes (Fig. 8C). ANOSIM results (Table 3) confirm a significant difference between the two groups. The average similarities within 'Canyon' and 'Open slope' groups are low (Table 6) and despite the high average dissimilarity between these groups, the variation in the specific composition of the assemblages does not show a clear trend. The most important contributors account for just $19.4 \%$ of the average dissimilarity; they are the polychaetes Phylamphicteis sp. Paradiopatra hispanica 
(A)

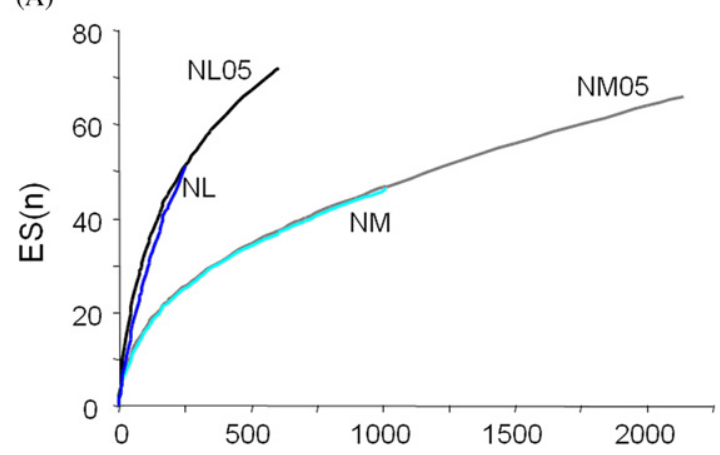

(C)

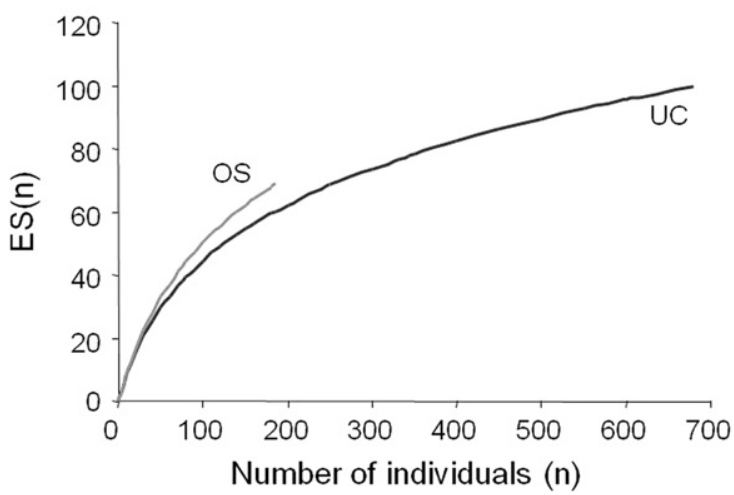

(B)

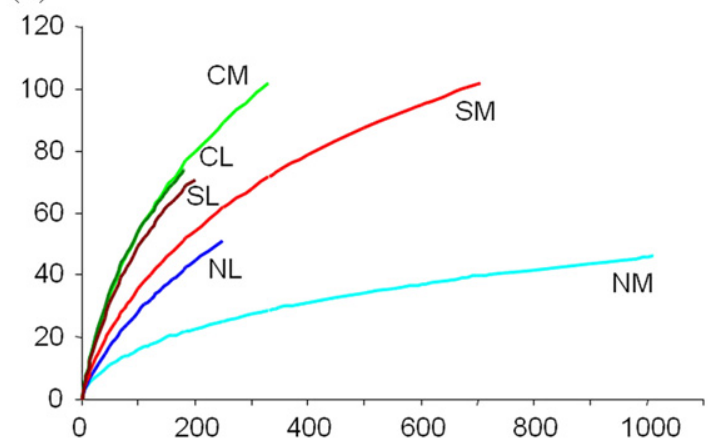

(D)

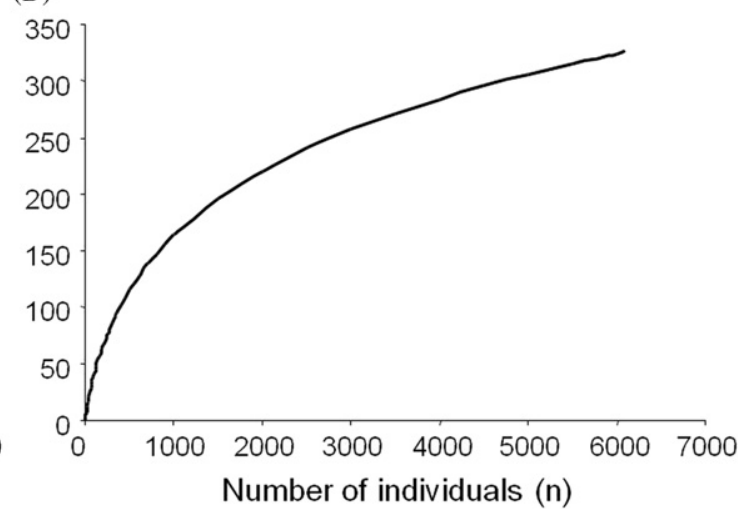

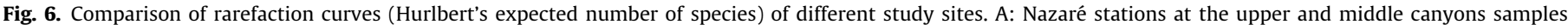

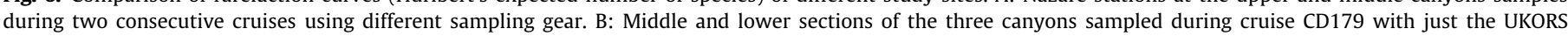

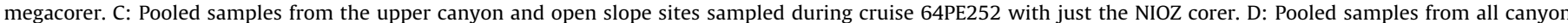

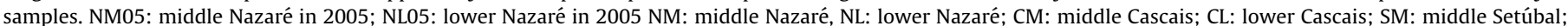
SL: lower Setúbal; UC: pooled upper canyon samples; OS: pooled open slope samples.
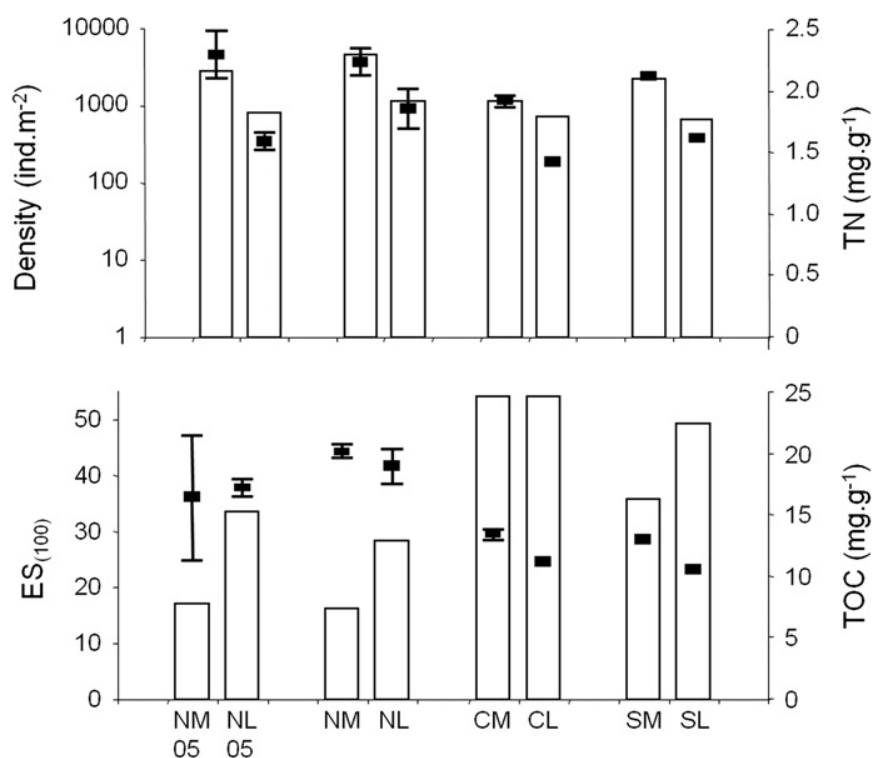

Fig. 7. Variation in the biogeochemical (average and standard error) and biological parameters (white bars) in the middle and lower section of the three studied canyons. Top: parallel trends in the variation of total nitrogen concentrations (TN) and macrofauna density (there is a significant positive Kendall correlation: $\tau=0.714 ; p<0.05)$. Bottom: opposite trends in the variation of total organic carbon concentrations $(\mathrm{TOC})$ and rarefaction biodiversity $\left(\mathrm{ES}_{(100)}\right)$ (there is a significant negative Kendall correlation: $\tau=-0.843 ; p<0.05$ ).

and the amphipod Carangoliopsis spinulosa. All are more abundant in canyons but are also present in at least one of the two open slope sites. The average total density of the macrofauna was significantly higher in canyons (average $\pm \mathrm{SE}: \mathrm{C}=495.6 \pm 43.51$; $\mathrm{OS}=189.8 \pm 22.26 ; t=5.523, \mathrm{df}=7, p<0.001)$. However, consistent high evenness values (Table 2) and low dominance (Fig. 5) occurred at all sites irrespective of their location. The low dominance and high heterogeneity of the assemblages result in pooled $\mathrm{ES}_{(100)}$ values for canyons (39.5) and for open slopes (44.3) that are higher than any of the individual sites (Table 2). Furthermore, the pooled rarefaction curves (Fig. 6C) suggest that biodiversity is lower in the upper canyons than in the adjacent open slopes at comparable depths.

\section{Discussion}

Evidence for the occurrence of spatial patterns, either geographic or bathymetric, in deep-sea macrofauna abundance, biomass, and diversity have been provided by several regionalscale studies (Rex, 1981, 1983; Stuart et al., 2001 and references therein). Abundance and biomass decrease exponentially with depth from the upper slope to the abyss. Typically deep-sea values are one or two orders of magnitude less than in coastal benthic systems (Rowe, 1983; Gage, 2003). Bathymetric gradients of species diversity are especially informative because they parallel steep environmental gradients in temperature, hydrostatic pressure, nutrient input, light intensity, sediment type and current dynamics over a relatively short geographic span (Gage and Tyler, 1991). A unimodal parabolic pattern of macroinvertebrate diversity vs. depth in the western North Atlantic was suggested by Rex $(1973,1981)$. Despite the high variability in diversity for a given depth and shifts in the depth of peak diversity $(1000-3000 \mathrm{~m})$ this pattern was replicated in other 
(A)

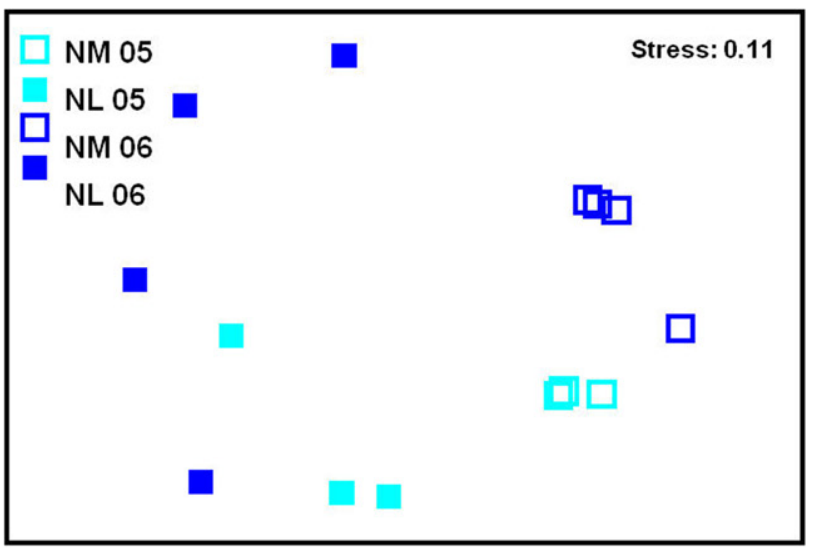

(B)

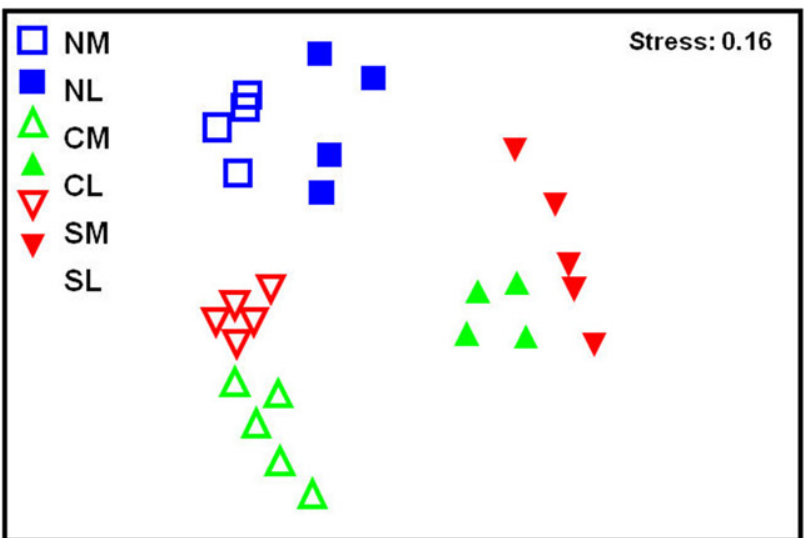

(C)

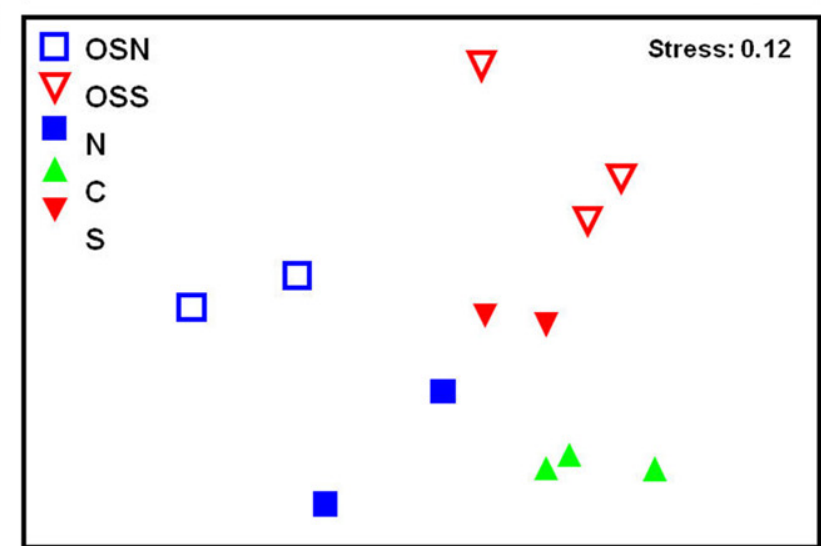

Fig. 8. MDS plots for the comparison between samples from: A Nazaré stations at the upper and middle canyons during two consecutive cruises using different sampling gear. B middle and lower sections of the three canyons sampled during cruise CD179 with just the UKORS megacorer. C Upper canyon and open slope sites sampled during cruise 64PE252 with just the NIOZ corer. NM05: middle Nazaré in 2005; NL05: lower Nazaré in 2005 NM: middle Nazaré, NL: lower Nazaré; CM: middle Cascais; CL: lower Cascais; SM: middle Setúbal; SL: lower Setúbal; NU: upper Nazaré, CU: upper Cascais; SU: upper Setùbal; OSN: open slope south of Nazaré; OSS: open slope south of Setúbal.

studies (Gage et al., 2000; Stuart et al., 2001 and references therein). However, this pattern is not universal because different taxonomic groups show a variety of patterns in different regions (e.g. Wilson, 1998) and particular environmental conditions at specific depths and localities may alter biodiversity trends (e.g. Levin and Gage, 1998; Vetter and Dayton, 1998). Studies on the benthic macrofauna of canyons are mostly limited to temperate and sub-tropical regions. Knowledge from these canyons indicates that they may be exceptions to the generalised patterns seen on the continental slope in terms of abundance, biomass and diversity patterns locally and regionally.
Table 3

Results of the ANOSIM global and pairwise tests. ANOSIM test 1: two-way crossed analysis with cruise (D279, CD179) and depth (3400 and $4300 \mathrm{~m}$ ) factors; ANOSIM test 2. two-way crossed analysis with depth $(3400$ and $4300 \mathrm{~m})$ and canyon (Nazaré, Setúbal and Cascais) factors, ANOSIM 3: one-way analysis for differences between canyons (C) and open slopes (OS).

\begin{tabular}{|c|c|c|c|c|}
\hline & $\begin{array}{l}\text { Sample } \\
\text { statistic }\end{array}$ & $\begin{array}{c}\text { Permutations } \\
\text { used }\end{array}$ & $\begin{array}{c}\text { Significant } \\
\text { statistics }\end{array}$ & $\begin{array}{c}\text { Significance } \\
\text { level }\end{array}$ \\
\hline \multicolumn{5}{|l|}{ ANOSIM test 1} \\
\hline Global tests & & & & \\
\hline Cruise & 0.435 & 999 & 11 & $1.2 \%^{*}$ \\
\hline Depth & 0.837 & $350^{\mathrm{a}}$ & 1 & $0.3 \%$ **k \\
\hline \multicolumn{5}{|l|}{$\begin{array}{c}\text { ANOSIM test } 2 \\
\text { Global tests }\end{array}$} \\
\hline Canyon & 0.823 & 9999 & 0 & $<0.1 \%^{* * * * *}$ \\
\hline Depth & 0.938 & 9999 & 0 & $<0.1 \%^{\text {*k*k }}$ \\
\hline \multicolumn{5}{|l|}{ Pairwise tests } \\
\hline Nazare, Cascais & 1.000 & 4410 (a) & 1 & $<0.1 \%^{\text {*kek }}$ \\
\hline Nazare, Setubal & 0.978 & 9999 & 0 & $<0.1 \%^{\text {*klk }}$ \\
\hline Cascais, Setubal & 0.584 & 9999 & 2 & $<0.1 \%^{* * k * k}$ \\
\hline \multicolumn{5}{|l|}{ ANOSIM test 3} \\
\hline C vs. OS & 0.526 & $792(a)$ & 1 & $0.1 \%$ *k \\
\hline
\end{tabular}

${ }^{a}$ All possible permutations.

* Significant.

*** Very significant.

**** Highly significant.

\subsection{Abundance and biomass}

Despite the generalised view that canyons are hotspots of macrofauna abundance and biomass, most studies focus only on bathymetric gradients or on a comparison of canyon and open slopes over a limited depth range. Comparisons between canyon macrofauna densities and those of the open slopes provided a range of results, including increased abundance and biomass (e.g. the upper Hudson Canyon, Rowe et al., 1982), increased biomass at different depths (e.g. the Whittard Canyon, Duineveld et al., 2001) and no significant differences in both variables (e.g. the upper Carson Canyon, Houston and Haedrich, 1984). In the Portuguese canyons previous studies have shown higher abundances in the lower Setúbal Canyon in comparison with the Tagus Abyssal Plain (Gage et al., 1995), and higher abundances in the middle and lower Nazaré Canyon in comparison with the open slope off Vigo (Cúrdia, 2001). In this study the upper section of all three canyons has greater faunal densities than the adjacent open slopes. Overall, the Portuguese canyons appear to conform to the general paradigm that canyons are areas of enhanced abundance and biomass (see Paterson et al., 2011).

Studies with good coverage of bathymetric gradients in canyons are rare. Where there are data, irregularities are seen in the expected trend of decreasing density with increasing depth. Peak or increased densities are often observed at intermediate depths (e.g. at $2560 \mathrm{~m}$ in Campeche Canyon, Escobar Briones et al., 2008; at $2715 \mathrm{~m}$ in the Whittard Canyon; Duineveld et al., 2001; at $2894 \mathrm{~m}$ in Nazaré Canyon, Curdia et al., 2004). In this study, higher densities were encountered consistently in the middle of all three Portuguese canyons (Nazaré: 3461-3522 m; Cascais: 3199-3219 m; Setúbal: 3224-3275 m).

\subsubsection{Environmental influences on abundance and biomass}

Because small-particle flux is the most important source of organic carbon to the deep ocean, large-scale patterns in the distribution of deep-sea benthic density, organism size and 
Table 4

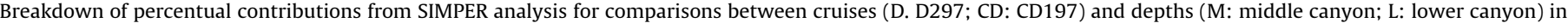
the Nazaré canyon. The taxa listed contribute at least $1 \%$. Numbers in bold mark the six dominant species in each site.

\begin{tabular}{|c|c|c|c|c|c|c|c|c|c|c|c|c|}
\hline & \multirow[t]{2}{*}{ Total } & \multicolumn{4}{|c|}{ Density (ind. $\mathrm{m}^{-2}$ ) } & \multirow[t]{2}{*}{ TG } & \multicolumn{3}{|c|}{ \% Contribution (Cruise) } & \multicolumn{3}{|c|}{ \% Contribution (Depth) } \\
\hline & & $\begin{array}{l}\text { NM05 } \\
2849.3\end{array}$ & $\begin{array}{l}\text { NL05 } \\
801.3\end{array}$ & $\begin{array}{l}\text { NM06 } \\
4599.5\end{array}$ & $\begin{array}{l}\text { NL06 } \\
1125.9\end{array}$ & & $\begin{array}{l}\text { D } \\
\text { AS: } 38.2\end{array}$ & $\begin{array}{l}\text { CD } \\
\text { AS: } 43.9\end{array}$ & $\begin{array}{l}\mathrm{D} / \mathrm{CD} \\
\mathrm{AD}: 66.3\end{array}$ & $\begin{array}{l}\text { M } \\
\text { AS: } 69.1\end{array}$ & $\begin{array}{l}\text { L } \\
\text { AS: } 44.7\end{array}$ & $\begin{array}{l}\mathrm{M} / \mathrm{L} \\
\mathrm{AD}: 79.0\end{array}$ \\
\hline \multicolumn{13}{|l|}{ Mollusca } \\
\hline Scaphopoda & & 72.0 & 9.3 & 114.3 & 4.0 & De & 2.45 & $\bullet$ & 1.82 & 2.73 & $\bullet$ & 2.37 \\
\hline Bivalvia und. & & 22.7 & 48.0 & 42.1 & 26.3 & $\mathrm{U}$ & 3.99 & 1.80 & 1.16 & $\bullet$ & 6.35 & $\bullet$ \\
\hline Nuculoida & Yoldiella spA & 108.0 & 2.7 & 110.6 & 9.1 & De & 2.12 & $\bullet$ & 2.25 & 2.76 & $\bullet$ & 2.82 \\
\hline Veneroida & Thyasira spC & 0.0 & 37.3 & 0.0 & 48.5 & $\mathrm{~S} / \mathrm{Ch}$ & 1.34 & $\bullet$ & 1.64 & - & 3.52 & 1.16 \\
\hline Chaetodermomorpha & & 1340.0 & 8.0 & 2279.4 & 0.0 & $\mathrm{De}$ & 20.39 & 20.73 & 33.68 & 54.12 & $\bullet$ & 48.12 \\
\hline \multicolumn{13}{|l|}{ Annelida } \\
\hline Scolecida & Levinsenia gracillis & 42.7 & 17.3 & 25.3 & 27.5 & De & 2.79 & $\bullet$ & $\bullet$ & $\bullet$ & 2.19 & $\bullet$ \\
\hline Aciculata & cf Sirsoe spB & 21.3 & 12.0 & 21.0 & 13.8 & $\mathrm{Co} ?$ & 1.77 & $\bullet$ & $\bullet$ & $\bullet$ & 1.73 & $\bullet$ \\
\hline \multirow[t]{6}{*}{ Canalipalpata } & Laubieriopsis cf. brevis & 64.0 & 6.7 & 42.3 & 4.5 & $\mathrm{U}$ & 1.75 & $\bullet$ & 1.17 & $\bullet$ & $\bullet$ & 1.36 \\
\hline & Siboglinum spA & 0.0 & 88.0 & 0.0 & 0.0 & $\mathrm{Ch}$ & 4.01 & $\bullet$ & 2.38 & - & 2.45 & 1.09 \\
\hline & Siboglinum ekmani & 0.0 & 0.0 & 0.0 & 22.7 & $\mathrm{Ch}$ & - & $\bullet$ & $\bullet$ & - & $\bullet$ & $\bullet$ \\
\hline & Prionospio cf. cirrifera & 0.0 & 28.0 & 0.0 & 11.9 & $\mathrm{De} / \mathrm{S}$ & 1.60 & $\bullet$ & $\bullet$ & - & 2.94 & $\bullet$ \\
\hline & Prionospio spA & 450.7 & 173.3 & 927.6 & 672.1 & $\mathrm{De} / \mathrm{S}$ & 28.63 & 62.39 & 20.30 & 18.50 & 61.42 & 10.53 \\
\hline & Prionospio spB & 18.7 & 13.3 & 23.8 & 4.5 & $\mathrm{De} / \mathrm{S}$ & 1.84 & $\bullet$ & $\bullet$ & $\bullet$ & $\bullet$ & $\bullet$ \\
\hline \multicolumn{13}{|l|}{ Arthropoda } \\
\hline \multirow[t]{3}{*}{ Tanaidacea } & Tanaidomorpha sp065 & 1.3 & 58.7 & 0.0 & 0.0 & De & 3.63 & - & 1.62 & $\bullet$ & 2.13 & $\bullet$ \\
\hline & cf. Colletidae sp052 & 1.3 & 32.0 & 0.0 & 4.0 & De & 1.71 & $\bullet$ & $\bullet$ & $\bullet$ & 1.62 & $\bullet$ \\
\hline & Pseudotanaidae sp051 & 289.3 & 29.3 & 414.0 & 20.4 & De & 7.86 & 5.39 & 6.26 & 10.91 & 3.97 & 8.69 \\
\hline \multicolumn{13}{|l|}{ Echinodermata } \\
\hline \multirow[t]{2}{*}{ Holothuroidea } & Ypsilothuria bitentaculata & 136.0 & 0.0 & 104.5 & 0.0 & De & 2.50 & $\bullet$ & 2.36 & 3.57 & - & 3.36 \\
\hline & Molpadia musculus & 22.7 & 0.0 & 102.7 & 0.0 & De & $\bullet$ & $\bullet$ & 1.52 & $\bullet$ & - & 1.73 \\
\hline$\%$ Contribution of selected taxa & 90.9 & 70.4 & 91.5 & 77.2 & & 88.4 & 90.3 & 76.2 & & 92.6 & 88.3 & 81.2 \\
\hline
\end{tabular}

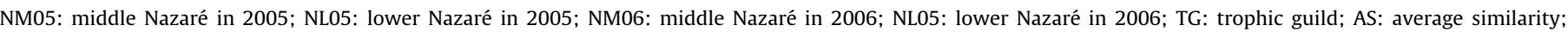
AD: Average dissimilarity; U: unknown; De: detritivores; S: suspension feeders; Ch: chemotrophs; Co: comensals; •: contributions lower than $1 \%$.

biomass have been related to large-scale patterns in primary productivity at the surface (Rowe, 1983; Thistle et al., 1985; Paterson et al., 1998; Gage, 2003; Paterson et al., 2006; Smith et al., 2008). Boyd and Newton (1999) suggested that variability in size-structure of the phytoplankton community, rather than primary production itself, is the cause of mass sinking of ungrazed algal cells. Shifts from picoplankton to diatom-based phytoplankton assemblages increase the flux of large quantities of fastsinking and highly labile material to the deep-sea (Buesseler et al., 2007; Smith et al., 2008). Alternating periods of upwelling and downwelling are likely to induce such shifts and subsequent episodic flux that represents a most important nutritional source for the deep-sea benthic community beneath such regions. In the East Atlantic Ocean, upwelling occurs in several regions along the African and Iberian margins. Galéron et al. (2009) mention upwelling as an important driver for the dense deep-sea benthic assemblages in the Congo channel. In the Portuguese margin, the occurrence of high-quality detrital flux is supported by reported 3-30 fold higher chlorophyll $a$ and 1.5-4 fold higher of organic carbon concentrations when compared to the Western Mediterranean (García et al., 2008; Pusceddu et al., 2010).

Further increased concentrations observed in the Nazare and Cascais canyons (Garcia and Thomsen, 2008; Ingels et al., 2009; Pusceddu et al., 2010) are likely to result from their effectiveness to capture sediment from lateral transport along the shelf. The Nazare Canyon is very active and captures predominantly material of terrigenous origin (Alt-Epping et al., 2007; de Stigter et al., 2007; Arzola et al., 2008). This refractory carbon is of very limited nutrient value but, although the higher $\mathrm{C}: \mathrm{N}$ values reflect the relative poor quality of the organic matter, macrofauna density and both TN and TOC concentrations were higher than in the Setúbal and Cascais canyons. Molar $\mathrm{C}: \mathrm{N}<8$ in Setúbal points to the high quality and predominantly marine origin of the organic matter in this canyon, TN concentrations are higher than in Cascais but TOC concentrations are similar. The significant correlation between TN and macrofauna abundance in the Portuguese canyons suggests that the amount of nitrogen-rich constituents (proteins, amino-acids) of the sediment may be more relevant than the total organic carbon loading (TOC) or the relative quality of the organic matter (C:N). Amaro et al. (2010) showed that, in the Portuguese canyons, protein concentrations in holothurians' guts were much higher than the other compounds and were efficiently digested as the material passed through the digestive tract. Carbohydrates and lipids were ingested in smaller amounts and digested with a much lower efficiency.

Increased food availability of high quality may be a major driver for the increased macrofauna abundance in the Portuguese canyons compared with adjacent open slope and for the differences apparent among canyons. However, it cannot fully explain the observed bathymetric trends. Biogeochemical samples were not collected in the upper canyon areas and therefore the observed correlation between TN and macrofauna density applies only to the middle and lower canyon sections. According to the concentrations of organic carbon and chlorophyll-a reported in previous studies (e.g. Pusceddu et al., 2010) higher abundance would be expected at the upper canyon sections but the observed values were the lowest in all of the three canyons studied. Data on environmental conditions in Cascais and Setúbal canyons are scarce, but in the Nazaré Canyon, where density fluctuations are more marked, a possible explanation may be found in the frequent disturbance of benthic communities from down canyon current events and the high sedimentation rates (de Stigter et al., 2007). The high, but predictable, disturbance may hinder population growth and select for more mobile and larger sized species that are able to forage more efficiently in the unstable, nutrient-rich sediments. 
Table 5

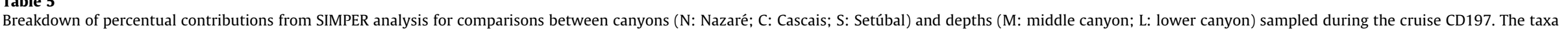
listed contribute at least $1 \%$. Numbers in bold mark the six dominant species in each site.

\begin{tabular}{|c|c|c|c|c|c|c|c|c|c|c|c|c|c|c|c|c|c|}
\hline & \multirow[t]{2}{*}{ Total } & \multicolumn{6}{|c|}{ Density (ind. $\mathrm{m}^{-2}$ ) } & \multirow[t]{2}{*}{ TG } & \multicolumn{6}{|c|}{ \% Contribution (Canyon) } & \multicolumn{3}{|c|}{ \% Contribution (Depth) } \\
\hline & & $\begin{array}{l}\text { NM } \\
4599.5\end{array}$ & $\begin{array}{l}\text { NL } \\
1125.9\end{array}$ & $\begin{array}{l}\text { CM } \\
1125.1\end{array}$ & $\begin{array}{l}\text { CL } \\
718.3\end{array}$ & $\begin{array}{l}\text { SM } \\
2241.3\end{array}$ & $\begin{array}{l}\text { SL } \\
653.4\end{array}$ & & $\begin{array}{l}\mathrm{N} \\
\text { AS: } 43.9\end{array}$ & $\begin{array}{l}\text { C } \\
\text { AS: } 21.6\end{array}$ & $\begin{array}{l}\text { S } \\
\text { AS: } 21.7\end{array}$ & $\begin{array}{l}\text { N/C } \\
\text { AD: } 93.1\end{array}$ & $\begin{array}{l}\text { N/S } \\
\text { AD: } 80.8\end{array}$ & $\begin{array}{l}\text { C/S } \\
\text { AD: } 85.2\end{array}$ & $\begin{array}{l}\text { M } \\
\text { AS: } 25.9\end{array}$ & $\begin{array}{l}L \\
\text { AS: } 21.1\end{array}$ & $\begin{array}{l}M / L \\
\text { AD: } 87.1\end{array}$ \\
\hline \multicolumn{18}{|l|}{ Mollusca } \\
\hline Scaphopoda und & & 114.3 & 4.0 & 10.9 & 0.0 & 12.7 & 0.0 & De & - & - & - & 1.3 & 1.3 & - & 1.4 & - & 1.1 \\
\hline Bivalvia und. & & 42.1 & 26.3 & 13.6 & 0.0 & 12.7 & 0.0 & $\mathrm{U}$ & 1.8 & 1.0 & - & & 1.0 & - & 1.5 & - & $\bullet$ \\
\hline \multirow[t]{2}{*}{ Nuculoida } & Yoldiella spA & 110.6 & 9.1 & 0.0 & 35.7 & 9.5 & 26.8 & De & - & 2.0 & 3.4 & 1.5 & 1.6 & 1.4 & - & 6.7 & 1.4 \\
\hline & cf. Ledella & 0.0 & 4.5 & 6.8 & 23.8 & 12.7 & 16.8 & De & - & 1.6 & 1.9 & - & - & 1.1 & - & 2.7 & - \\
\hline \multirow[t]{2}{*}{ Veneroida } & Thyasira cf. flexuosa & 0.0 & 0.0 & 88.1 & 0.0 & 66.7 & 0.0 & $\mathrm{Ch} / \mathrm{S}$ & - & 6.9 & $\bullet$ & 1.6 & - & 2.9 & 5.2 & - & 2.8 \\
\hline & Thyasira spC & 0.0 & 48.5 & 0.0 & 19.8 & 0.0 & 17.3 & $\mathrm{Ch} / \mathrm{S}$ & - & - & - & 1.2 & 1.3 & - & - & 4.2 & 1.0 \\
\hline Chaetodermomorpha & & 2279.4 & 0.0 & 14.5 & 7.9 & 12.7 & 0.0 & De & 20.7 & 1.2 & - & 22.2 & 23.7 & - & 11.9 & - & 14.2 \\
\hline \multicolumn{18}{|l|}{ Annelida } \\
\hline \multirow[t]{5}{*}{ Scolecida } & Notomastus sp. & 0.0 & 0.0 & 15.9 & 19.8 & 0.0 & 3.2 & De & - & 1.9 & - & - & - & 1.1 & - & - & - \\
\hline & Notoproctus oculatus & 0.0 & 9.3 & 0.0 & 19.8 & 9.5 & 23.1 & $\mathrm{De}$ & - & 1.7 & 2.9 & - & - & 1.0 & - & 6.7 & - \\
\hline & Ophelina cf. abranchiata & 10.4 & 9.3 & 0.0 & 19.8 & 19.0 & 0.0 & De & - & 1.7 & $\bullet$ & - & - & - & - & 1.8 & - \\
\hline & Aricidea $\mathrm{spC}$ & 0.0 & 0.0 & 0.0 & 19.8 & 0.0 & 16.3 & $\mathrm{De}$ & - & 1.1 & 1.7 & - & - & - & - & 3.7 & - \\
\hline & Levinsenia gracillis & 25.3 & 27.5 & 10.0 & 4.0 & 73.0 & 3.2 & De & - & $\bullet$ & 2.5 & - & 1.4 & 1.6 & 2.2 & 1.1 & 1.4 \\
\hline \multirow{6}{*}{ Aciculata } & Paraonella sp. & 0.0 & 7.9 & 3.6 & 23.8 & 0.0 & 16.8 & $\mathrm{De}$ & - & 2.8 & $\bullet$ & $\bullet$ & $\bullet$ & $\bullet$ & $\bullet$ & 4.9 & $\bullet$ \\
\hline & cf. Sirsoe spB & 21.0 & 13.8 & 0.0 & 0.0 & 3.2 & 6.3 & $\mathrm{Co}$ ? & - & - & - & - & - & - & - & 1.0 & - \\
\hline & Aglaophamus elemellata & 20.4 & 0.0 & 10.4 & 4.0 & 28.6 & 0.0 & $0 ?$ & - & - & - & - & - & - & 1.1 & - & - \\
\hline & Ceratocephale loveni & 10.4 & 20.5 & 0.0 & 35.7 & 9.5 & 9.5 & 0 ? & - & 2.0 & 1.1 & - & - & 1.1 & $\bullet$ & 4.1 & - \\
\hline & Sigambra sp. & 7.9 & 0.0 & 3.2 & 4.0 & 22.2 & 7.3 & $\mathrm{Ca} / \mathrm{O}$ & - & - & 1.2 & - & • & - & - & - & - \\
\hline & Laenira minor & 4.0 & 4.0 & 10.0 & 7.9 & 3.2 & 13.2 & $\mathrm{Ca}$ & - & 1.5 & 2.0 & - & - & - & - & 2.9 & - \\
\hline \multirow{10}{*}{ Canalipalpata } & Glyphanostomum spA & 0.0 & 0.0 & 3.2 & 7.9 & 0.0 & 55.4 & $\mathrm{~S} / \mathrm{De}$ & - & $\bullet$ & 5.6 & - & 1.4 & 2.1 & - & 4.6 & 1.1 \\
\hline & Melinampharete spA & 0.0 & 0.0 & 3.2 & 0.0 & 231.7 & 0.0 & $\mathrm{~S} / \mathrm{De}$ & - & - & 6.5 & - & 3.3 & 4.6 & 2.9 & - & 3.4 \\
\hline & Monticelina annulosa & 0.0 & 0.0 & 0.0 & 27.8 & 0.0 & 53.6 & De & - & 1.4 & 4.0 & - & 1.3 & 2.0 & - & 6.6 & 1.3 \\
\hline & Laubieriopsis cf. brevis & 42.3 & 4.5 & 13.6 & 0.0 & 9.5 & 3.2 & $\mathrm{U}$ & - & - & - & $\bullet$ & - & - & 1.3 & - & $\bullet$ \\
\hline & Siboglinum cf. angustum & 0.0 & 9.1 & 69.0 & 27.8 & 3.2 & 0.0 & $\mathrm{Ch}$ & - & 12.5 & - & 1.7 & - & 2.8 & 2.1 & - & 1.6 \\
\hline & Siboglinum cf. ekmani & 0.0 & 22.7 & 41.3 & 4.0 & 12.7 & 0.0 & $\mathrm{Ch}$ & - & 1.2 & - & 1.1 & - & 1.3 & $\bullet$ & - & 1.1 \\
\hline & Siboglinum cf. leucopleurum & 0.0 & 0.0 & 0.0 & 0.0 & 6.3 & 79.4 & $\mathrm{Ch}$ & - & - & 1.9 & $\bullet$ & 1.9 & 2.8 & - & - & 1.3 \\
\hline & Prionospio spA & 927.6 & 672.1 & 27.2 & 15.9 & 796.8 & 0.0 & De/S & 62.4 & 5.5 & 27.7 & 25.9 & 21.3 & 14.9 & 36.2 & 20.7 & 17.1 \\
\hline & Prionospio spB & 23.8 & 4.5 & 60.9 & 0.0 & 149.2 & 6.3 & $\mathrm{De} / \mathrm{S}$ & - & 1.9 & 5.2 & 1.2 & 2.2 & 3.4 & 6.1 & $\bullet$ & 3.2 \\
\hline & Prionospio spD & 0.0 & 4.0 & 10.0 & 4.0 & 15.9 & 12.7 & $\mathrm{De} / \mathrm{S}$ & - & 1.3 & 1.4 & $\bullet$ & $\bullet$ & $\bullet$ & $\bullet$ & - & • \\
\hline \multicolumn{18}{|l|}{ Arthropoda } \\
\hline \multirow{3}{*}{ Amphipoda } & Haploops cf. setosa & 0.0 & 0.0 & 13.2 & 0.0 & 0.0 & 0.0 & $\mathrm{~s}$ & - & 1.2 & - & - & - & - & - & - & - \\
\hline & Harpinia spp. & 0.0 & 0.0 & 19.0 & 15.9 & 34.9 & 0.0 & & - & 3.3 & 1.2 & - & - & 1.2 & 1.8 & - & - \\
\hline & Amphipoda sp072 & 0.0 & 0.0 & 3.6 & 0.0 & 31.7 & 3.2 & $\mathrm{U}$ & - & $\bullet$ & 1.6 & - & - & $\bullet$ & $\bullet$ & $\bullet$ & $\bullet$ \\
\hline Cumacea & Lampropidae sp018 & 0.0 & 0.0 & 48.1 & 0.0 & 0.0 & 0.0 & De & - & 2.7 & - & - & - & 1.3 & - & - & 1.0 \\
\hline Isopoda & Desmosomatidae und. & 4.0 & 0.0 & 13.6 & 7.9 & 6.3 & 10.0 & De & - & 3.0 & 1.5 & - & - & • & - & 1.4 & $\bullet$ \\
\hline & Chelator cf.insignis & 0.0 & 17.6 & 26.3 & 19.8 & 15.9 & 9.5 & $\mathrm{De}$ & - & 6.2 & 1.8 & - & - & 1.2 & 1.6 & 2.6 & - \\
\hline & Haploniscus cf.charcoti & 0.0 & 0.0 & 0.0 & 0.0 & 57.1 & 0.0 & De & - & - & 1.7 & - & - & 1.1 & $\bullet$ & - & - \\
\hline & Ischnomesus cf. norvegicus & 0.0 & 0.0 & 0.0 & 11.9 & 0.0 & 13.2 & De & - & - & $\bullet$ & - & - & $\bullet$ & - & 1.6 & - \\
\hline & Macrostylis cf. abyssicola & 0.0 & 0.0 & 60.4 & 0.0 & 34.9 & 6.3 & $\mathrm{De}$ & - & 3.7 & 1.8 & 1.2 & - & 2.0 & 3.0 & - & 1.8 \\
\hline & Macrostylis magnifica & 0.0 & 0.0 & 14.1 & 15.9 & 15.9 & 0.0 & De & - & 2.3 & - & - & - & - & - & - & - \\
\hline & Rapaniscus sp095 & 0.0 & 0.0 & 0.0 & 31.7 & 0.0 & 0.0 & $\mathrm{De}$ & - & 1.5 & - & - & - & - & - & - & - \\
\hline & cf. Thambema sp093 & 0.0 & 0.0 & 20.0 & 0.0 & 9.5 & 3.6 & De & - & 1.3 & - & $\bullet$ & - & - & - & - & - \\
\hline Tanaidacea & Tanaidomorpha sp048 & 0.0 & 0.0 & 23.1 & 11.9 & 0.0 & 0.0 & De & - & 4.1 & - & - & - & 1.0 & - & - & - \\
\hline & cf. Anarthuridae sp013 & 0.0 & 4.0 & 14.1 & 4.0 & 19.0 & 6.3 & $\mathrm{De}$ & - & 1.2 & 1.1 & $\bullet$ & $\bullet$ & $\bullet$ & $\bullet$ & $\bullet$ & $\bullet$ \\
\hline & $\begin{array}{l}\text { Pseudotanaidae sp051 } \\
\text { Pand }\end{array}$ & 414.0 & 20.4 & 3.2 & 11.9 & 19.0 & 16.3 & De & 5.4 & 1.6 & $\begin{array}{l}1.1 \\
3.1\end{array}$ & 4.4 & 4.6 & $\bullet$ & 2.8 & 6.0 & 3.0 \\
\hline Echinodermata & & & & & & & & & & & & & & & & & \\
\hline Holothuroidea & Ypsilothuria bitentaculata & 104.5 & 0.0 & 0.0 & 0.0 & 0.0 & 0.0 & De & - & - & - & 1.0 & 1.1 & - & - & - & - \\
\hline & Molpadia musculus & 102.7 & 0.0 & 0.0 & 0.0 & 0.0 & 0.0 & De & - & - & - & 1.0 & 1.1 & - & - & - & - \\
\hline$\%$ Contribution of selected taxa: & 92.7 & 83.8 & 59.9 & 64.6 & 78.8 & 67.2 & & 90.5 & 81.1 & 82.8 & 65.3 & 68.3 & 51.8 & & 81.1 & 83.3 & 57.7 \\
\hline
\end{tabular}

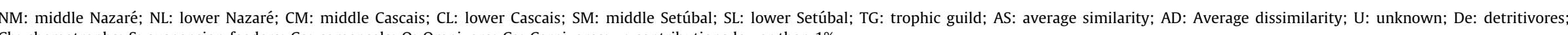
Ch: chemotrophs; S: suspension feeders; Co: comensals; O: Omnivore; Ca: Carnivores; $\bullet$ : contributions lower than $1 \%$. 
Table 6

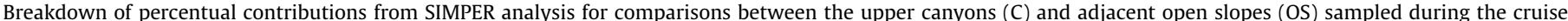
64PE252. The taxa listed contribute at least $1 \%$. Numbers in bold mark the six dominant species in each site.

\begin{tabular}{|c|c|c|c|c|c|c|c|c|c|c|}
\hline & \multirow[t]{2}{*}{ Total } & \multicolumn{5}{|c|}{ Density (ind. $\mathrm{m}^{-2}$ ) } & \multirow[t]{2}{*}{ TG } & \multicolumn{3}{|c|}{$\%$ Contribution } \\
\hline & & $\begin{array}{l}\text { NU } \\
474.5\end{array}$ & $\begin{array}{l}\text { CU } \\
583.3\end{array}$ & $\begin{array}{l}\text { SU } \\
385.2\end{array}$ & $\begin{array}{l}\text { OSN } \\
191.3\end{array}$ & $\begin{array}{l}\text { OSS } \\
188.8\end{array}$ & & $\begin{array}{l}\text { C } \\
\text { AS: } 32.6\end{array}$ & $\begin{array}{l}\text { OS } \\
\text { AS: } 25.1\end{array}$ & $\begin{array}{l}\text { C/OS } \\
\text { AD: } 80.5\end{array}$ \\
\hline \multicolumn{11}{|l|}{ Mollusca } \\
\hline Scaphopoda und & & 28.1 & 5.1 & 0.0 & 5.1 & 1.7 & De & 1.32 & 2.97 & 1.70 \\
\hline Nuculoida & cf. Ledella & 0.0 & 1.7 & 0.0 & 2.6 & 3.4 & De & $\bullet$ & 2.74 & $\bullet$ \\
\hline Veneroida & Abra sp. & 10.2 & 6.8 & 0.0 & 0.0 & 1.7 & $\mathrm{~S}$ & $\bullet$ & $\bullet$ & 1.04 \\
\hline Chaetodermomorpha & & 25.5 & 5.1 & 5.1 & 2.6 & 0.0 & De & 1.49 & $\bullet$ & 1.77 \\
\hline \multicolumn{11}{|l|}{ Annelida } \\
\hline \multirow[t]{7}{*}{ Scolecida } & Notomastus spB & 5.1 & 0.0 & 2.6 & 5.1 & 3.4 & De & $\bullet$ & 3.58 & $\bullet$ \\
\hline & Maldanidae spB & 2.6 & 1.7 & 15.3 & 2.6 & 5.1 & De & 1.14 & $\bullet$ & 1.35 \\
\hline & Maldanidae spD & 0.0 & 22.1 & 17.9 & 0.0 & 1.7 & $\mathrm{De}$ & 5.40 & $\bullet$ & 2.59 \\
\hline & Polyphthalmus sp & 7.7 & 10.2 & 0.0 & 0.0 & 3.4 & De & 1.78 & 1.24 & $\bullet$ \\
\hline & Scoloplos cf. armiger & 2.6 & 0.0 & 0.0 & 0.0 & 5.1 & De & $\bullet$ & 3.27 & $\bullet$ \\
\hline & Aricidea sp. & 0.0 & 3.4 & 2.6 & 7.7 & 1.7 & $\mathrm{De}$ & $\bullet$ & 3.58 & $\bullet$ \\
\hline & Levinsenia sp. & 2.6 & 25.5 & 12.8 & 2.6 & 3.4 & De & 4.08 & 2.74 & 2.31 \\
\hline \multirow[t]{6}{*}{ Aciculata } & Glycera capitata & 5.1 & 8.5 & 15.3 & 5.1 & 1.7 & $\mathrm{Ca}$ & 3.62 & 2.97 & 1.41 \\
\hline & Abyssoninoe abyssorum & 33.2 & 5.1 & 10.2 & 0.0 & 0.0 & $\mathrm{Ca} / \mathrm{O}$ & 4.44 & - & 2.67 \\
\hline & Lumbrineris fragilis & 17.9 & 0.0 & 0.0 & 0.0 & 0.0 & $\mathrm{Ca} / \mathrm{O}$ & $\bullet$ & - & 1.14 \\
\hline & Aglaophamus pulcher & 0.0 & 20.4 & 10.2 & 0.0 & 1.7 & $\mathrm{O} ?$ & 3.40 & $\bullet$ & 1.97 \\
\hline & Paradiopatra hispanica & 66.3 & 11.9 & 7.7 & 33.2 & 0.0 & $\mathrm{Ca} / \mathrm{O}$ & 6.55 & 4.24 & 4.90 \\
\hline & Polynoidae sp. & 0.0 & 42.5 & 7.7 & 0.0 & 3.4 & $\mathrm{Ca} ?$ & 4.37 & $\bullet$ & 3.36 \\
\hline \multirow[t]{5}{*}{ Canalipalpata } & Phylamphicteis sp. & 2.6 & 110.5 & 40.8 & 7.7 & 3.4 & S/De & 15.56 & 3.23 & 9.68 \\
\hline & Chaetozone sp. & 0.0 & 3.4 & 0.0 & 0.0 & 11.9 & $\mathrm{De}$ & - & 2.84 & 1.34 \\
\hline & Laubieriopsis cf. brevis & 12.8 & 8.5 & 2.6 & 2.6 & 0.0 & $\mathrm{U}$ & 3.14 & $\bullet$ & 1.33 \\
\hline & Prionospio sandersi & 20.4 & 34.0 & 23.0 & 17.9 & 6.8 & $\mathrm{De} / \mathrm{S}$ & 10.91 & 15.05 & 3.08 \\
\hline & Polycirrus cf. latidens & 12.8 & 0.0 & 10.2 & 5.1 & 1.7 & $\mathrm{De}$ & 2.12 & $\bullet$ & 1.21 \\
\hline \multicolumn{11}{|l|}{ Arthropoda } \\
\hline \multirow[t]{5}{*}{ Amphipoda } & Amphipoda und. & 0.0 & 6.8 & 2.6 & 2.6 & 3.4 & $\mathrm{U}$ & $\bullet$ & 3.00 & $\bullet$ \\
\hline & Haploops cf. setosa & 0.0 & 0.0 & 0.0 & 0.0 & 6.8 & $\mathrm{~S}$ & - & 3.27 & $\bullet$ \\
\hline & Carangoliopsis spinulosa & 74.0 & 1.7 & 23.0 & 0.0 & 20.4 & De & 6.45 & 10.87 & 4.86 \\
\hline & Harpinia spp. & 0.0 & 17.0 & 10.2 & 0.0 & 10.2 & De & 1.77 & 2.84 & 1.89 \\
\hline & Metaphoxus sp050 & 0.0 & 17.0 & 2.6 & 0.0 & 1.7 & De & 1.65 & $\bullet$ & 1.34 \\
\hline \multirow[t]{2}{*}{ Cumacea } & Leucon sp004 & 10.2 & 22.1 & 0.0 & 0.0 & 1.7 & De & 3.06 & $\bullet$ & 1.98 \\
\hline & Leucon sp005 & 0.0 & 13.6 & 2.6 & 0.0 & 0.0 & De & 1.13 & - & 1.11 \\
\hline \multirow[t]{3}{*}{ Isopoda } & Desmosomatidae und. & 10.2 & 3.4 & 5.1 & 0.0 & 3.4 & De & 1.95 & $\bullet$ & 1.03 \\
\hline & Chelator cf. insignis & 10.2 & 10.2 & 0.0 & 0.0 & 0.0 & $\mathrm{De}$ & 1.29 & - & 1.19 \\
\hline & Eugerda tetarta & 5.1 & 15.3 & 0.0 & 0.0 & 5.1 & $\mathrm{De}$ & 1.16 & $\bullet$ & 1.49 \\
\hline \multirow[t]{5}{*}{ Tanaidacea } & Apseudes cf. grossimanus & 0.0 & 0.0 & 2.6 & 0.0 & 5.1 & De & $\bullet$ & 3.27 & $\bullet$ \\
\hline & Apseudidade sp037 & 0.0 & 0.0 & 0.0 & 0.0 & 10.2 & De & - & 3.27 & 1.14 \\
\hline & Apseudidae & 0.0 & 0.0 & 17.9 & 5.1 & 10.2 & $\mathrm{De}$ & $\bullet$ & 12.00 & 1.74 \\
\hline & cf. Colletea sp046 & 58.7 & 0.0 & 0.0 & 0.0 & 0.0 & De & $\bullet$ & - & 3.47 \\
\hline & cf. Tanaellidae sp040 & 5.1 & 3.4 & 10.2 & 0.0 & 1.7 & De & $\bullet$ & $\bullet$ & 1.08 \\
\hline \multicolumn{11}{|l|}{ Echinodermata } \\
\hline \multirow[t]{3}{*}{ Ophiuroidea } & Ophiocantha sp016 & 0.0 & 0.0 & 0.0 & 12.8 & 1.7 & S/De & - & $\bullet$ & 1.06 \\
\hline & Amphipholis squamata & 2.6 & 5.1 & 2.6 & 0.0 & 6.8 & S/De & $\bullet$ & 3.27 & $\bullet$ \\
\hline & Ophiuroid juveniles & 0.0 & 17.0 & 0.0 & 0.0 & 0.0 & S/De & $\bullet$ & - & 1.18 \\
\hline$\%$ Contribution of selected taxa & 90.9 & 78.7 & 68.2 & 62.7 & 79.3 & & 87.8 & 90.2 & 67.4 & \\
\hline
\end{tabular}

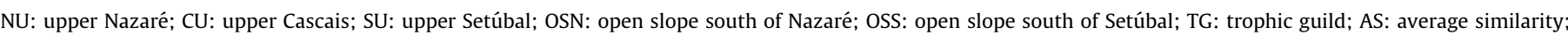
AD: Average dissimilarity; De: detritivores; S: suspension feeders; Ca: Carnivores; O: Omnivores; U: unknown; •: contributions lower than 1\%.

\subsection{Biodiversity}

Studies on the biodiversity of canyons have referred generally only to major taxonomic groups or trophic guilds and are therefore of limited use for comparisons with the present study. However, some comparisons with other deep-sea studies are possible. In the Portuguese canyons rarefaction diversity estimates are highly variable both locally and from canyon to canyon. The values from pooled samples in Nazare are among the lowest $\mathrm{ES}_{(100)}$ estimates in comparison with different deep-sea regions reviewed by Snelgrove and Smith (2002). Setúbal matches the average (50) and Cascais matches the highest value (63) reported from the North Carolina slope (Blake and Grassle, 1994).

The high density and dominance of the assemblages in the middle section of Nazaré and Setúbal was accompanied by depressed values in the species richness resulting in an inverted pattern of the unimodal bathymetric trend evident in many continental slope environments (e.g. Rex, 1981). In Cascais, the bathymetric pattern in diversity showed a better match to this trend with increasing values of expected species richness from the upper to the middle canyon, but maintained high expected species richness at the lower section. It therefore seems probable that altered and localised environmental conditions in the Portuguese canyons play an important role and override the more common bathymetric patterns.

\subsubsection{Environmental influences and canyon biodiversity}

Gradients of productivity, sediment heterogeneity, hydrodynamic regimes and catastrophic physical disturbance are major players in canyon environments and important drivers of the community structure and biodiversity of their fauna. Levin et al. 
(2001) reviewed the environmental influences on deep-sea species diversity; diversity is expected to show a unimodal relationship both with food input and flow strength gradients as predicted by theories such as the Intermediate Disturbance Hypothesis (Connell, 1978) and the Intermediate Productivity Hypothesis (Grime, 1973) and to respond positively to sediment heterogeneity. In the deep-sea these relationships are plausible but often not well substantiated because the environmental factors are interdependent and act in ways that are not entirely understood (Levin et al., 2001).

The significant negative correlation between $\mathrm{ES}_{(100)}$ and TOC concentrations observed in the middle and lower sections of the three Portuguese canyons is in line with other studies in canyons (Vetter and Dayton, 1998) and other deep-sea areas that show decreased diversity associated with high organic loading (Levin et al., 2001 and references therein). Levin and Gage (1998) also found a positive correlation between dominance and sediment POC concentrations in the deep Indo-Pacific. Low diversity in organic-rich areas, such as in middle and to a lesser extent in the lower section of Nazaré Canyon, is often coupled with high dominance possibly as a result from tolerance to physiological stress and/or differential numerical response of opportunist species to organic loading. In the generally nutrient-poor environment of the deep-sea this trend can be interpreted as representing the descending portion of the unimodal relationship between diversity and food input (Levin et al., 2001).

The effects of currents on benthic diversity may be positive or negative and operate in complex ways by acting on other environmental factors and biological processes. Near bottom flows in excess of $20-25 \mathrm{~cm} \mathrm{~s}^{-2}$ will potentially depress diversity directly by eroding superficial sediments (Levin et al., 2001 and references therein). Current speed measurements in the Nazaré Canyon (de Stigter et al. 2007) showed that values reached 30$35 \mathrm{~cm} \mathrm{~s}^{-1}$ at $343 \mathrm{~m}$ (2-day deployment) but rarely exceeded $20 \mathrm{~cm} \mathrm{~s}^{-1}$ at $1126 \mathrm{~m} \mathrm{9-day} \mathrm{deployment).} \mathrm{In} \mathrm{the} \mathrm{middle} \mathrm{and} \mathrm{lower}$ sections deployments were longer ( 8 and 6 months, respectively) and revealed very regular semi-diurnal variation with spring-tide maxima reaching $25-35 \mathrm{~cm} \mathrm{~s}^{-1}$ and periodically resuspending the sediments at $3010 \mathrm{~m}$ while at $4298 \mathrm{~m}$ much weaker currents were measured (semi-diurnal maxima of $10-15 \mathrm{~cm} \mathrm{~s}^{-1}$ ). According to Levin et al. (2001) periodic disturbance by erosive flow creates repeated opportunities for recolonization and ensures that the benthic fauna remains in an early successional state, favouring high dominance by opportunists (e.g. spionid polychaetes).

In the lower section of the Nazaré and Setúbal canyons, Arzola et al. (2008) mapped different bedforms and, generally, a high heterogeneity in the distribution of sediments. Varied distribution of sediment grain sizes influences organic content and may enable resource partitioning and higher faunal diversity (Levin et al., 2001) Such high heterogeneity in the lower canyon sediments may be reflected in the higher faunal diversity recorded.

\subsubsection{Trophic diversity}

In general, most deep-sea organisms are deposit feeders (Jumars and Wheatcroft, 1989) and the macrofaunal assemblages in the Portuguese canyons are clearly dominated by this feeding guild. The manner, in which detrital particles are dealt with by the deep-sea benthic assemblage as food, is closely scaled to body size (Jumars et al., 1990; Gage, 2003) and therefore the deposit feeding guild may encompass a wide taxonomic diversity. This is evident, for instance in the middle canyon in Nazaré where larger animals such as molpadiid holothurians ingest food in bulk as particles forming part of the sediment while the smaller tanaids feed selectively on individual particles in the same way as other metazoans of meiofaunal size. Intermediate size detritus feeders include polychaete (e.g. Levinsenia gracilis) and mollusc species (e.g. Chaetodermomorpha and Scaphopoda).

Interestingly, spionid polychaetes are the most common opportunists in the Portuguese canyons. These 'interface' feeders can switch from feeding on organic particles lying on the sediment surface to suspension feeding, depending on flow energy (Taghon et al., 1980; Dauer et al., 1981). They may be very effective in removing suspended material from near-bed flow (Thomsen et al., 1995) and clearly benefit from the hydrodynamic regime in the Portuguese canyons. Spionid polychates were also found to be dominant in other deep-sea regions subjected to upwelling regimes and terrestrial organic inputs (Galéron et al., 2009).

Strictly suspension feeders that generally benefit from moderate current flow (Rowe, 1971) are absent in the middle section of Nazaré, but several species in this trophic group are present in the upper and lower sections as well as in the other two canyons. Other feeding groups such as omnivores and carnivores or scavengers are only well-represented at the upper canyons where the higher biomass of the macrofaunal assemblages may support higher trophic levels.

Noteworthy is the presence of obligate or potential chemotrophs (Siboglinidae:Frenulata and Thyasiridae) in the middle and lower sections of the Portuguese canyons. In shallow water, diversity in chemical pathways allows benthic organisms to extract energy from reduced organic matter over a range of oxic and anoxic conditions, but in the deep sea organic inputs are rarely sufficient for labile particles to escape utilization in the sediment (Gage, 2003). Canyons may be an exception as the high organic loading and relatively high sedimentation rates may create conditions for the occurrence of reducing environments. The presence of frenulate siboglinids and thyasirid bivalves is indicative of the occurrence of such conditions. Thyasirids are usually small bivalves that show a wide variation in the extent of their nutritional reliance upon symbionts (Southward, 1986; Dufour, 2005). Although relatively few chemotrophic species are associated with strictly chemosynthetic environments, Thyasirids are widespread in deep sea reducing sediments including vegetation-derived organic-rich environments (Southward, 1986; Oliver and Holmes, 2006; Rodrigues et al., 2008). Frenulate siboglinids are typically found in cold seeps (Hilário et al., 2010) but have been also reported from canyon environments (Flügel and Callsen-Cencic, 1993; Southward and Dando, 1998) These polychaetes lack a digestive system and obtain most of their nutrition from the endosymbiotic bacteria (Southward et al., 1981; Southward, 1982; Spiro et al., 1986). However, there is evidence that many species, including Siboglinum eckmani, are mixotrophic, deriving their nutrition from both dissolved organic matter and from the endosymbiotic sulphuroxidising bacteria (Southward and Southward, 1982; Southward et al., 1986; Dando et al., 2008). The absence of these frenulate siboglinids from the middle section of the Nazare Canyon may be explained by the high rates of bioturbation by other fauna (e.g. molpadiid holothurians) leading to an additional increase in the rate of chemical and microbial oxidation of sulphides in the sediment that is known to reduce the carrying capacity of the sediment for siboglinids (Dando et al., 2008).

\section{Conclusions}

The benthic macrofauna of the Portuguese canyons showed important variations in taxonomic and functional composition, abundance, biodiversity and community structure. Abundance in the upper canyons was significantly higher than in the adjacent slopes and in all canyons bathymetric trend was identical with peak abundances at intermediate depths. Depressed biodiversity coupled with high dominance occurred in the middle sections of 
the Nazaré and Setúbal canyons, but high biodiversity and low dominance were maintained along the depth gradient in the Cascais Canyon. In the middle and lower sections of the canyons, a positive correlation between macrofauna abundance and TN, and a negative correlation between biodiversity and TOC were found, confirming that organic loading is probably the major driver for structuring canyon benthic assemblages through a series of mechanisms that act on the availability of food and partitioning of resources by different species. Food inputs are most likely coupled with surface productivity and hydrodynamic regimes, and interact with disturbance by sedimentation/resuspension processes and sediment heterogeneity that are also relevant for the macrofaunal assemblages.

Our results provide additional evidence for the view of canyons as important disruptions in abundance, biomass and diversity patterns both locally and regionally. They also show that even at a relatively narrow regional scale $(100 \mathrm{~s} \mathrm{~km})$ these patterns are not consistent. The general lack of taxonomic resolution in canyon studies does not allow answering the controversy on whether or not canyons are hotspots of biodiversity. However the present study suggests that canyons may show multiple patterns of biodiversity in relation to the adjacent margins, generated by complex, localised interactions of several environmental drivers and the differential response of organisms and populations.

\section{Acknowledgments}

Thanks are due to the chief scientists, scientific parties, captains and crews of the R.R.S. Discovery, R.R.S. Charles Darwin and R.V. Pelagia for the support during the cruises D297, CD179 and 64PE252. Dário Mendes Alves is acknowledged by his participation in sampling during the cruises CD179 and 64PE252 and by sorting the biological samples. This work was funded by the HERMES project (EC contract number GOCE-CT-511234) under the European Commission's Framework Six Programme and from the HERMIONE project, grant agreement no 226354, under the European Community's Seventh Framework Programme. This is a contribution to the Census of Marine Life project COMARGE (Continental Margin Ecosystems on a worldwide scale). The following authors were supported by Fundação para a Ciência e Tecnologia: TA (SFRH/BPD/21459/2005), AH (SFRH/ BPD/22383/2005), AR (SFRH/BD/16563/2004), CFR (SFRH/BD/17085/ 2004).

\section{References}

Alt-Epping, U., Mil-Homens, M., Hebbeln, D., Abrantes, F., Schneider, R.R., 2007. Provenance of organic matter and nutrient conditions on a river- and upwelling influenced shelf: a case study from the Portuguese Margin. Marine Geology 243, 169-179.

Amaro, T., Bianchelli, S., Pusceddu, A., Danovaro, R., Billett, D.S.M., Cunha, M.R., 2010. The trophic biology of Molpadia musculus at $3500 \mathrm{~m}$ in the Nazaré Canyon. Biogeosciences 7, 1-14.

Arzola, R.G., Wynn, R.B., Lastras, G., Masson, D.G., Weaver, P.P.E., 2008. Sedimentary features and processes in the Nazaré and Setúbal submarine canyons, west Iberian margin. Marine Geology 250, 64-88.

Billett, D.S.M., Lampitt, R.S., Rice, A.L., Mantoura, R.F.C., 1983. Seasonal sedimentation of phytoplankton in the deepsea benthos. Nature 302, 520-522.

Billet, D.S.M., shipboard scientific party, 2006. RRS Charles Darwin Cruise CD179, 14 April-17 May 2006. Hotspot ecosystem research in the Setúbal, Lisbon, Cascais and Nazaré canyons on the Portuguese continental margin. HERMES reports. National Oceanography Centre, Southampton, pp. 66.

Blake, J.A., Grassle, J.F., 1994. Benthic community structure on the U.S. South Atlantic slope off the Carolinas: spatial heterogeneity in a current-dominated system. Deep-Sea Research II 41, 835-874.

Boyd, P.W., Newton, P.P., 1999. Does plankton community structure determine downward particulate organic carbon flux in different oceanic provinces? Deep-Sea Research I 46, 63-91.

Buesseler, K.O., Lamborg, C.H., Boyd, P.W., Lam, P.J., Trull, T.W., Bidigare, R.R., Bishop, J.K.B., Casciotti, K.L., Dehairs, F., Elskens, M., Honda, M., Karl, D.M., Siegel, D.A., Silver, M.W., Steinberg, D.K., Valdes, J., Van Mooy, B., Wilson, S.,
2007. Revisiting carbon flux through the ocean's Twilight Zone. Science 316 (5824), 567-570

Canals, M., Puig, P., de Madron, X.D., Heussner, S., Palanques, A., Fabres, J., 2006 Flushing submarine canyons. Nature 444, 354-357.

Clarke, K.R., Gorley, R.N., 2006. Primer v6: User Manual/Tutorial. Primer-E, Plymouth $190 \mathrm{pp}$

Company, J.B., Puig, P., Sarda, F., Palanques, A., Latasa, M., Scharek, R., 2008 Climate influence on deep sea populations. PLoS One 3, 1-8.

Connell, J.H., 1978. Diversity in tropical rain forests and coral reefs. Science 199, $1302-1310$.

Cordes, E., Cunha, M.R., Galéron, J., Mora, C., Olu-Le-Roy, K., Sibuet, M., Van Gaever, S. Vanreusel, A., Levin, L., 2010. The influence of geological, geochemical, and biogenic habitat heterogeneity on seep biodiversity. Marine Ecology 31 (1), 51-65.

Cúrdia, J., 2001. Deep-sea macrofaunal assemblages in the Iberian Margin Continental slope off Vigo and Nazaré Submarine Canyon. M.Sc. Thesis, Universidade de Aveiro, Aveiro, pp. 103+Annexes.

Curdia, J., Carvalho, S., Ravara, A., Gage, J.D., Rodrigues, A.M., Quintino, V., 2004. Deep macrobenthic communities from Nazaré Submarine Canyon (NW Portugal). Scientia Marina 68, 171-180.

Dando, P.R., Southward, A.J., Southward, E.C., Lamont, P., Harvey, R., 2008. Interactions between sediment chemistry and frenulate pogonophores (Annelida) in the north-east Atlantic. Deep-Sea Research I 55, 966-996.

Dauer, D.M.C., Maybury, C.A., Ewing, R.M., 1981. Feeding behavior and general ecology of several spionid polychaetes from the Chesapeake Bay. Journal of Experimental Marine Biology and Ecology 54, 21-38.

De Leo, F.C., Smith, C.R., Rowden, A.A., Bowden, D.A., Clark, M.R., 2010. Submarine canyons: hotspots of benthic biomass and productivity in the deep sea. Proceedings of the Royal Society B 277 (1695), 2783-2792.

de Stigter, H.C., Boer, W., de Jesus Mendes, P.A., Jesus, C.C., Thomsen, L., van den Bergh, G., van Weering, C.E., 2007. Recent sediment transport and deposition in the Nazare Canyon, Portuguese continental margin. Marine Geology 246, 144-164.

de Stigter, H., shipboard scientific party, 2006. Report of cruise 64PE252 with RV Pelagia. Cascais - Lisbon, 30 August-21 September 2006. Anthropogenic lead on the Portuguese continental margin. HERMES reports. Royal Netherlands Institute for Sea Research, Texel, pp. 57.

Dufour, S., 2005. Gill anatomy and the evolution of symbiosis in the bivalve family Thyasiridae. Biological Bulletin 208, 200-212.

Duineveld, G., Lavaleye, M., Berghuis, E., de Wilde, P., 2001. Activity and composition of the benthic fauna in the Whittard Canyon and the adjacent continental slope (NE Atlantic). Oceanologica Acta 24, 69-83.

Escobar Briones, E., Estrada Santillán, E.L., Legendre, P., 2008. Macrofaunal density and biomass in the Campeche Canyon, Southwestern Gulf of Mexico. Deep-Sea Research II 55, 2679-2685.

Flügel, H.J., Callsen-Cencic, P., 1993. A new species of the genus Siboglinum (Pogonophora) from the North Atlantic off Portugal. Sarsia 78, 255-263.

Gage, J.D., 2003. Food inputs, utilization, carbon flow and energetics. In: Tyler, P.A (Ed.), Ecosystems of the World, vol.28: Ecosystems of Deep Oceans. Elsevier, Amsterdam, pp. 315-382.

Gage, J.D., Lamont, P.A., Kroeger, K., Paterson, G.L.J., Gonzalez Vecino, J.L., 2000 Patterns of deep-sea macrobenthos at the continental margin: standing crop, diversity and faunal change on the continental slope off Scotland. Hydrobiologia 440, 261-271.

Gage, J.D., Lamont, P.A., Tyler, P.A., 1995. Deep-sea macrobenthic communities at contrasting sites off Portugal, preliminary results: I. introduction and diversity comparisons. Internationale Revue gesamten Hydrobiologie 80 (2), 235-250.

Gage, J.D., May, R.M., 1993. Biodiversity-a dip into the deep seas. Nature 365 609-610.

Gage, J.D., Tyler, P.A., 1991. Deep-Sea Biology: A Natural History of Organisms at the Deep-Sea Floor. Cambridge University Press, Cambridge 504 pp.

Galéron, J., Menot, L., Renaud, N., Crassous, P., Khripounoff, A., Treignier, C., Sibuet, M., 2009. Spatial and temporal patterns of benthic macrofaunal communities on the deep continental margin in the Gulf of Guinea. Deep-Sea Research II 56 2299-2312.

Garcia, R., Thomsen, L., 2008. Bioavailable organic matter in surface sediments of the Nazaré Canyon and adjacent slope (Western Iberian Margin). Journal of Marine Systems 74 (1-2), 44-59.

García, R, van Oevelen, D., Soetaert, K., Thomsen, L., De Stigter, H.C., Epping, E. 2008. Deposition rates, mixing intensity and organic content in two contrasting submarine canyons. Progress in Oceanography 76, 192-215.

Gardner, W.D., 1989. Periodic resuspension in Baltimore Canyon by focusing of internal waves. Journal of Geophysical Research 94, 18185-18194.

Gooday, A.J., 2002. Biological responses to seasonally varying fluxes of organic matter to the ocean floor: a review. Journal of Oceanography 58, 305-332.

Grime, J.P., 1973. Competitive exclusion in herbaceous vegetation. Nature 242 (5396), 344-347.

Hilário, A., Johnson, S.B., Vrijenhoek, R.C., Cunha, M.R., 2010. High diversity of frenulates (Polychaeta: Siboglinidae) in the Gulf of Cadiz mud volcanoes: a DNA taxonomy analysis. Deep Sea Research I 57, 143-150.

Houston, K.A., Haedrich, R.L., 1984. Abundance and biomass of macrobenthos in the vicinity of Carson submarine Canyon, northwest Atlantic Ocean. Marine Biology 82, 301-305.

Hurlbert, S.H., 1971. The nonconcept of species diversity: a critique and alternative parameters. Ecology 52, 577-586.

Ingels, J., Kiriakoulakis, K., Wolff, G.A., Vanreusel, A., 2009. Nematode diversity and its relation to the quantity and quality of sedimentary organic matter in the 
deep Nazaré Canyon, Western Iberian Margin. Deep-Sea Research I 56, 1521-1539.

Jumars, P.A., Wheatcroft, R.A., 1989. Responses of benthos to changing food quality and quantity, with a focus on deposit feeding and bioturbation. In: Berger W.H., Smetacek, V.S., Wefer, G. (Eds.), Productivity of the Ocean: Present and Past. Wiley, Chichester, pp. 235-253.

Jumars, P.A., Mayer, L.M., Deming, J.W., Baross, J.A., Wheatcroft, R.A., 1990. Deep-sea deposit feeding strategies suggested by environmental and feeding constraints. Philosophical Transactions of the Royal Society London Series A 331, 85-101.

Kendall, M.G., 1938. A new measure of rank correlation. Biometrika 30 (1-2), 81-93.

Lambshead, P.J.D., Platt, H.M., Shaw, K.M., 1983. The detection of differences among assemblages of marine benthic species based on an assessment of dominance and diversity. Journal of Natural History 17, 859-874.

Lastras, G., Arzola, R.G., Masson, D.G., Wynn, R.B., Huvenne, V.A.I., Hühnerbach, V., Canals, M., 2009. Geomorphology and sedimentary features in the Centra Portuguese submarine canyons, Western Iberian margin. Geomorphology 103 (3), 310-329.

Leibold, M.A., Holyoak, M., Mouquet, N., Amarasekare, P., Chase, J.M., Hoopes, M.F. 2004. The metacommunity concept: a framework for multi-scale community ecology. Ecology Letters 7, 601-613.

Levin, L.A., Etter, R.J., Rex, M.A., Gooday, A.J., Smith, C.R., Pineda, J., Stuart, C.T., Hessler, R.R., Pawson, D., 2001. Environmental influences on regional deep-sea species diversity. Annual Review of Ecology and Systematics 32, 51-93.

Levin, L.A., Gage, J.D., 1998. Relationships between oxygen, organic matter and the diversity of bathyal macrofauna. Deep-Sea Research II 45, 129-163.

McClain, C.R., Barry, J.P., 2010. Habitat heterogeneity, disturbance, and productivity work in concert to regulate biodiversity in deep submarine canyons. Ecology 91 (4), 964-976.

Oliveira, A., Santos, A.I., Rodrigues, A., Vitorino, J., 2007. Sedimentary particle distribution and dynamics on the Nazaré Canyon system and adjacent shelf (Portugal). Marine Geology 246 (2-4), 105-122.

Oliver, P.G., Holmes, A.M., 2006. New species of Thyasiridae (Bivalvia) from chemosynthetic communities in the Atlantic Ocean. Journal of Conchology 39 (2), 175-184.

Palanques, A., Garcia-Ladona, E., Gomis, D., Martín, J., Marcos, M., Pascual, A., Puig P., Emelianov, M., Guillén, J., Gili, J.M., Tintoré, J., Jordi, A., Basterretxeab, G. Font, J., Segura, M., Blasco, D., Monserrat, S., Ruiz, S., Pagès, F., 2005. Genera patterns of circulation, sediment fluxes and ecology of the Palamós (La Fonera) submarine canyon, northwestern Mediterranean. Progress in Oceanography $66,89-119$.

Paterson, G.L.J., Wilson, G.D.F., Cosson, N., Lamont, P.A., 1998. Hessler and Jumars (1974) revisited: abyssal polychaete assemblages from the Atlantic and Pacific. Deep-Sea Research II 45, 225-251.

Paterson, G.L.J., Glover, A.G., Tilman, C., 2006. Body size response of abyssa polychaetes to different nutrient regimes. Scientia Marina 70S3, 319-330.

Paterson, G.L.J., Glover, A.G., Cunha, M.R., Neal, L., de Stitger, H., Kiriakoulakis, K., Billett, D.S.M., Wolff, G., Tiago, A., Ravara, A., Lamont, P., Tyler, P.A., 2011 Disturbance, productivity and diversity in deep-sea canyons: a worm's eye view. Deep-Sea Research II 58, 2448-2460.

Pielou, E.C., 1969. An Introduction to Mathematical Ecology, pp. Wiley-Interscience, New York

Pusceddu, A., Bianchelli, S., Canals, M., Sanchez-Vidal, A., De-Madron, X.D., Heussner, S., Lykousis, V., de-Stigter, H., Trincardi, F., Danovaro, R., 2010. Organic matter in sediments of canyons and open slopes of the Portuguese, Catalan, Southern Adriatic and Cretan Sea margins. Deep-Sea Research I 57, 441-457.

Quaresma, L.S., Vitorino, J., Oliveira, A., da Silva, J., 2007. Evidence of sediment resuspension by nonlinear internal waves on the western Portuguese midshelf. Marine Geology 246 (2-4), 123-143.

Relvas, P., Barton, E.D., Dubert, J., Oliveira, P.B., Peliz, A., Silva, J.C., Santos, A.M. 2007. Physical oceanography of Western Iberian Ecosystem: latest views and challenges. Progress in Oceanography 74, 149-173.

Rex, M.A., 1973. Deep-sea species diversity: decreased gastropod diversity at abyssal depths. Science 181, 1051-1053.

Rex, M.A., 1981. Community structure in the deep-sea benthos. Annual Review of Ecology and Systematics 12, 331-353.

Rex, M.A., 1983. Geographic patterns of species diversity in the deep-sea benthos. In: Rowe, G.T. (Ed.), The Sea, Deep- Sea Biology, Vol. 8. Wiley, New York, pp. 453-472.

Rex, M.A., Etter, R.J., Morris, J.S., Crouse, J., McClain, C.R., Johnson, N.A., Stuart, C.T., Thies, R., Avery, R., 2006. Global bathymetric patterns of standing stock and body size in the deep-sea benthos. Marine Ecology Progress Series 317, 1-8.

Rodrigues, C.F., Oliver, P.G., Cunha, M.R., 2008. Thyasiroidea (Mollusca: Bivalvia) from the mud volcanoes of the Gulf of Cadiz (North-east Atlantic). Zootaxa 1752, 41-56.

Rogers, A., Billett, D., Berger, W., Flach, E., Freiwald, A., Gage, J.D., Hebbeln, D., Heip, C. Pfannkuche, O., Ramirez-Llodra, E., Medlin, L., Sibuet, M., Soetaert, K. Tendal, O., Vanreusel, A., Wlodarska-Kowalczuk, M., 2002. Life at the edge: achieving prediction from environmental variability and biological variety. In: Wefer, G., Billet, D., Jorgensen, B.B., Schluter, M., Van Weering, T. (Eds.), Ocean Margin Systems. Springer-Verlag, Berlin Heidelberg, pp. 387-404.

Rowe, G.T., 1971. Observations on bottom currents and epibenthic populations in Hatteras Submarine Canyon. Deep-Sea Research 18, 569-581.

Rowe, G.T., 1981. The deep-sea ecosystem. In: Longhurst, A.R. (Ed.), Analysis of Marine Ecosystems. Academic Press, New York, pp. 235-267.

Rowe, G.T., 1983. Biomass and production of the deep-sea macrobenthos. In: Rowe, G.T. (Ed.), The Sea, Deep-Sea Biology, Vol. 8. Wiley, New York, pp. 97-121.
Rowe, G.T., Polloni, P.T., Haedrich, R.L., 1982. The deep-sea macrobenthos on the continental margin of the northwest Atlantic Ocean. Deep-Sea Research 29 (2A), 257-278.

Sampere, T.P., Bianchi, T.S., Wakeham, S.G., Allison, M.A., 2008. Sources of organic matter in surface sediments of the Louisiana Continental margin: effects of major depositional/transport pathways and Hurricane Ivan. Continental Shelf Research 28, 2472-2487.

Sanders, H.L., Hessler, R.R., Hampson, G.R., 1965. An introduction to the study of deep-sea benthic faunal assemblages along the Gay Head-Bermuda transect. Deep-Sea Research 12, 845-867.

Schlacher, T.A., Schlacher-Hoenlinger, M.A., Williams, A., Althaus, F., Hooper, J.A., Kioser, R., 2007. Richness and distribution of sponge megabenthos in continental margin canyons off southeastern Australia. Marine Ecology Progress Series 340, 73-78.

Shepard, F.P., Marshall, N.F., McLoughlin, P.A., 1974. Currents in submarine canyons. Deep-Sea Research 21, 691-706.

Smith, C.R., De Leo, F.C., Bernardino, A.F., Sweetman, A.K., Martinez Arbizu, P., 2008. Abyssal food limitation, ecosystem structure and climate change. Trends in Ecology \& Evolution 23 (9), 518-528.

Snelgrove, P.V.R., Smith, C.R., 2002. A riot of species in an environmental calm: the paradox of species-rich deep-sea floor. Oceanography and Marine Biology: an Annual Review 40, 311-342.

Southward, A.J., Dando, P.R., 1998. Distribution of Pogonophora in canyons of the Bay of Biscay: factors controlling abundance and depth range. Journal of the Biological Association of the United Kingdom 68, 627-638.

Southward, A.J., Southward, E.C., 1982. The role of dissolved organic matter in the nutrition of deep-sea benthos. American Zoologist 22, 647-659.

Southward, A.J., Southward, E.C., Dando, P.R., Barrett, R.L., Ling, R., 1986. Chemoautotrophic function of bacterial symbionts in small Pogonophora. Journal of the Marine Biological Association of the United Kingdom 66, 415-437.

Southward, A.J., Southward, E.C., Dando, P.R., Rau, G.H., Felbeck, H., Flügel, H., 1981. Bacterial symbionts and low 13C/12C ratios in tissues of Pogonophora indicate unusual nutrition and metabolism. Nature 293, 616-620.

Southward, E.C., 1982. Bacterial symbionts in Pogonophora. Journal of the Marine Biological Association of the United Kingdom 62, 889-906.

Southward, E.C., 1986. Gill symbionts in thyasirids and other bivalve molluscs. Journal of the Marine Biological Association of the United Kingdom 66, 889-914.

Spiro, B., Greenwood, P.B., Southward, A.J., Dando, P.R., 1986. 13C/12C ratios in marine invertebrates from reducing sediments: confirmation of nutritional importance of chemoautotrophic endosymbiotic bacteria. Marine Ecology Progress Series 28, 233-240.

Stuart, C.T., Rex, M.A., Etter, R.J., 2001. Large scale spatial and temporal patterns of deep sea benthic species diversity. In: Tyler, P.A. (Ed.), Ecosystems of the World, Ecosystems of Deep Oceans, vol. 28. Elsevier, Amsterdam, pp. 295-311.

Taghon, G.L., Nowell, A.R.M., Jumars, P.A., 1980. Induction of suspension feeding in spionid polychaetes by high particulate fluxes. Science 210, 562-564.

Thistle, D., Yingst, J.Y., Fauchald, D., 1985. A deep-sea benthic community exposed to strong near-bottom currents on the Scotian Rise (Western Atlantic). Marine Geology 66, 91-112.

Thistle, D., Wilson, G.D.F., 1996. Is the HEBBLE isopod fauna hydrodynamically modified? A second test. Deep-Sea Research I 43 (4), 545-554.

Thomsen, L., Graf, G., von Juterzenka, K., Witte, U., 1995. An in situ experiment to investigate the depletion of seston above an interface feeder field on the continental margin of the western Barents Sea. Marine Ecology Progress Series 123, 295-300.

Tyler, P., Amaro, T., Arzola, R., Cunha, M.R., de Stigter, H., Gooday, A., Huvenne, V., Ingels, J., Kiriakoulakis, K., Lastras, G., Masson, D., Oliveira, A., Pattenden, A., Vanreusel, A., Van Weering, T., Vitorino, J., Witte, U., Wolff, G., 2009. Europe's Grand Canyon: Nazaré submarine canyon. Oceanography 22, 46-57.

Van Weering, T.C.E., de Stigter, H.C., Boer, W., de Haas, H., 2002. Recent sediment transport and accumulation on the NW Iberian margin. Progress in Oceanography 52, 349-371.

Vetter, E.W., 1994. Hotspots of benthic production. Nature 372, 47.

Vetter, E.W., 1995. Detritus-based patches of high secondary production in the nearshore benthos. Marine Ecology Progress Series 120, 251-262.

Vetter, E.W., Dayton, P.K., 1998. Macrofaunal communities within and adjacent to a detritus-rich submarine canyon system. Deep-Sea Research II 45, 25-54.

Vetter, E.W., Smith, C.R., De Leo, F.C., 2010. Hawaiian hotspots: enhanced megafaunal abundance and diversity in submarine canyons on the oceanic islands of Hawaii. Marine Ecology 31, 183-199.

Vitorino, J., Oliveira, A., Jouanneau, J.M., Drago, T., 2002. Winter dynamics on the northern Portuguese shelf. Part 1: physical processes. Progress in Oceanography $52(2-4), 129-153$

Weaver, P.P.E., Billett, D.S.M., Boetius, A., Danovaro, R., Freiwald, A., Sibuet, M., 2004. Hotspot ecosystem research on Europe's deep-ocean margins. Oceanography 17 (4), 132-143.

Weaver, P.P.E., shipboard scientific party, 2005. RRS Discovery Cruise D297, 27 July 16 August 2005. The geobiology of the Nazaré and Setúbal Canyons, Portuguese Continental Margin. HERMES reports. National Oceanography Centre, Southampton, pp. 41

Wilson, G.D.F., 1998. Historical influences on deep-sea isopod diversity in the Atlantic Ocean. Deep-Sea Research II 45, 279-301.

Yamamouro, M., Kayanne, H., 1995. Rapid direct determination of organic carbon and nitrogen in carbonate-bearing sediments with a Yanaco MT-5 CHN analyser. Limnology and Oceanography 40, 1001-1005. 